\title{
The Largest Group of Superficial Neocortical GABAergic Interneurons Expresses Ionotropic Serotonin Receptors
}

\author{
SooHyun Lee, ${ }^{1,2,3,4 \star}$ Jens Hjerling-Leffler, ${ }^{1,4 \star}$ Edward Zagha, ${ }^{1,2,3}$ Gord Fishell, ${ }^{1,4}$ and Bernardo Rudy ${ }^{1,2,3}$ \\ ${ }^{1}$ Smilow Neuroscience Program, Departments of ${ }^{2}$ Physiology and Neuroscience, ${ }^{3}$ Biochemistry, and ${ }^{4}$ Cell Biology, Smilow Research Center, New York \\ University School of Medicine, New York, New York 10016
}

\begin{abstract}
A highly diverse population of neocortical GABAergic inhibitory interneurons has been implicated in multiple functions in information processing within cortical circuits. The diversity of cortical interneurons is determined during development and primarily depends on their embryonic origins either from the medial (MGE) or the caudal (CGE) ganglionic eminences. Although MGE-derived parvalbumin (PV)- or somatostatin (SST)-expressing interneurons are well characterized, less is known about the other types of cortical GABAergic interneurons, especially those of CGE lineage, because of the lack of specific neuronal markers for these interneuron subtypes. Using a bacterial artificial chromosome transgenic mouse line, we show that, in the somatosensory cortex of the mouse, the serotonin 5-hydroxytryptamine $3 \mathrm{~A}\left(5-\mathrm{HT}_{3 \mathrm{~A}}\right)$ receptor, the only ionotropic serotonergic receptor, is expressed in most, if not all, neocortical GABAergic interneurons that do not express PV or SST. Genetic fate mapping and neurochemical profile demonstrate that 5- $\mathrm{HT}_{3 \mathrm{~A}} \mathrm{R}-$ expressing neurons include the entire spectrum of CGE-derived interneurons. We report that, in addition to serotonergic responsiveness via 5- $\mathrm{HT}_{3 \mathrm{~A}} \mathrm{Rs}$, acetylcholine also depolarizes $5-\mathrm{HT}_{3 \mathrm{~A}} \mathrm{R}$-expressing neurons via nicotinic receptors. $5-\mathrm{HT}_{3 \mathrm{~A}} \mathrm{R}$-expressing neurons in thalamocortical (TC) recipient areas receive weak but direct monosynaptic inputs from the thalamus. TC input depolarizes a subset of TC-recipient 5- $\mathrm{HT}_{3 \mathrm{~A}} \mathrm{R}$ neurons as strongly as fast-spiking cells, in part because of their high input resistance. Hence, fast modulation of serotonergic and cholinergic transmission may influence cortical activity through an enhancement of GABAergic synaptic transmission from $5-\mathrm{HT}_{3 \mathrm{~A}} \mathrm{R}$-expressing neurons during sensory process depending on different behavioral states.
\end{abstract}

\section{Introduction}

Neuromodulator systems provide a mechanism by which small groups of neurons in subcortical nuclei can broadly influence cortical activity. Conversely, disruption of such modulation may impair various physiological processes and can potentially lead to neurological disorders (Freund, 2003; Lewis and Hashimoto, 2007). The profound influence of these neuromodulators on the cortex, likely in part stems from their preferential targeting of inhibitory cortical interneurons releasing GABA (Beaulieu and Somogyi, 1991; Smiley and Goldman-Rakic, 1996). Cortical GABAergic interneurons play critical roles in controlling activity through feedforward and feedback inhibition (Freund and Buzsáki, 1996; McBain and Fisahn, 2001; Freund, 2003; Buzsáki et al., 2004) and are heterogeneous with regards to their developmental origin, expression of neurochemical markers, electrophysiological properties, morphology, and cellular and subcellular location of output synaptic contacts (Ascoli et al., 2008).

Received April 11, 2010; revised Aug. 18, 2010; accepted Sept. 13, 2010.

This work was supported by National Institutes of Health Grants NS30989 and NS045217 (B.R.) and R01MS226557 and R01NS039007 (G.F.). S.L. is supported by the Patterson Trust Fellowship. J.H.-L. is supported by a long-term European Molecular Biology Organization Fellowship and the Swedish Society for Medical Research. We thank members of the Rudy and Fishell Laboratories for their advice and support.

*S.L. and J.H.-L. contributed equally to this manuscript.

Correspondence should be addressed to Bernardo Rudy, Smilow Neuroscience Program, Departments of Physiology and Neuroscience and Biochemistry, Smilow Center, New York University School of Medicine, 522 First Avenue, New York, NY 10016. E-mail: bernardo.rudy@nyumc.org.

DOI:10.1523/JNEUROSCI.1869-10.2010

Copyright $\odot 2010$ the authors $\quad 0270-6474 / 10 / 3016796-13 \$ 15.00 / 0$
Understanding cortical interneuron diversity is critical to understanding the emergence and function of cortical networks.

Here, we focus on cortical interneurons that express the 5-hydroxytryptamine (serotonin) receptor $3 \mathrm{~A}\left(5-\mathrm{HT}_{3 \mathrm{~A}} \mathrm{R}\right)$, which is the only known murine serotonergic ionotropic receptor (Barnes and Sharp, 1999; Chameau and van Hooft, 2006). In the mature neocortex the $5-\mathrm{HT}_{3 \mathrm{~A}} \mathrm{R}$ is present exclusively in GABAergic interneurons (Morales and Bloom, 1997; Chameau and van Hooft, 2006), including vasoactive intestinal peptide (VIP)and/or cholecystokinin (CCK)-positive bipolar cells and multipolar neuropeptide Y (NPY)-expressing cells (Férézou et al., 2002; Inta et al., 2008; Varga et al., 2009; Vucurovic et al., 2010). However, the full extent of the expression of the $5-\mathrm{HT}_{3 \mathrm{~A}} \mathrm{R}$ in cortical interneurons and the representation of $5-\mathrm{HT}_{3 \mathrm{~A}} \mathrm{R}$-expressing interneurons of the total interneuron population are unknown. This knowledge is critical to understand the function of fast serotonergic signaling in cortex. By taking advantage of 5HT3aR-BAC ${ }^{E G F P}$ transgenic mice, we have undertaken a systematic approach to understanding the population of $5-\mathrm{HT}_{3 \mathrm{~A}} \mathrm{R}$-expressing interneurons in somatosensory cortex. We find that the population of $5-\mathrm{HT}_{3 \mathrm{~A}} \mathrm{R}-$ expressing interneurons is large, particularly in supragranular layers, in which it represents the major interneuron population. In fact, nearly all interneurons that do not express parvalbumin (PV) or somatostatin (SST) are 5- $\mathrm{HT}_{3 \mathrm{~A}} \mathrm{R}$ expressing. Thus, most, if not all, cortical interneurons can be assigned to one of three groups, PV-, SST-, or 5- $\mathrm{HT}_{3 \mathrm{~A}} \mathrm{R}$-expressing interneurons.

Although PV and SST are derived from the medial ganglionic eminence (MGE), the caudal ganglionic eminence (CGE) is the 
origin of most interneurons that do not express these markers (Nery et al., 2002; Xu et al., 2004; Butt et al., 2005; Cobos et al., 2006; Miyoshi et al., 2010). This includes the reelin-expressing late-spiking neurogliaform cells as well as bipolar/bitufted VIPexpressing cells. Using genetic fate mapping, we directly show the CGE origin of a majority of $5-\mathrm{HT}_{3 \mathrm{~A}} \mathrm{R}$-expressing neurons and exclude the MGE as a source. Accordingly, we find the same anatomical and electrophysiological subtypes as those described in the CGEderived population. Although heterogeneous, the $5-\mathrm{HT}_{3 \mathrm{~A}} \mathrm{R}$ expressing populations uniformly respond to serotonergic and cholinergic modulation. In addition, a subpopulation of these interneurons receives weak thalamocortical (TC) inputs whose influence on cortical networks might be functionally gated by their serotonergic input. Thus, $5-\mathrm{HT}_{3 \mathrm{~A}} \mathrm{R}$-expressing interneurons are uniquely posed to influence cortical sensory processes through their ability to convey fast effects of convergent long-range cortical afferents. Some of these data have been presented in abstract form (Zagha et al., 2005).

\section{Materials and Methods}

In vivo fate mapping. To perform genetic fate mapping of the CGE and MGE, respectively, male mouse mutants for Mash1-BAC ${ }^{\text {CreER }}$ (heterozygous or homozygous) (Battiste et al., 2007) or Nkx2-1-BAC Cre (heterozygous) (Xu et al., 2008) on a R26R ${ }^{\text {tdRFP }}$ (homozygous) background (Luche et al., 2007) was crossed to $5 H T 3 a R-B A C^{E G F P}$ (heterozygous) females. In the case of inducible genetic fate mapping using the Mash1-BAC CreER, 4 mg of tamoxifen was administered orally between noon and 2:00 P.M. at embryonic day 12.5 (E12.5), E14.5, and E16.5.

Tissue preparation for immunocytochemistry and in situ hybridization. For in situ, postnatal brains were fixed by transcardiac perfusion followed by $1 \mathrm{~h}$ postfixation with 4\% PFA on ice. Embryonic brains were dissected and then fixed overnight in $4 \%$ paraformaldehyde (PFA) at $4^{\circ} \mathrm{C}$. Brain tissue was cryoprotected using a $15 \%$ followed by $30 \%$ sucrose/PBS solution overnight at $4^{\circ} \mathrm{C}$. Tissues were embedded in Tissue-Tek, frozen on dry ice, and sectioned at $20 \mu \mathrm{m}$. For immunohistochemistry, mice were fixed by transcardiac perfusion with $0.9 \%$ saline containing heparin (1 $\mathrm{U} / \mathrm{ml}$ ), followed by $30-50 \mathrm{ml}$ of $0.1 \mathrm{~m}$ phosphate buffer, $\mathrm{pH} 7.4$, containing $4 \%$ paraformaldehyde. Dissected brains were further fixed in the same fixative solution for $1 \mathrm{~h}$ at $4^{\circ} \mathrm{C}$ and then placed in a $30 \%$ sucrose solution at $4^{\circ} \mathrm{C}$ for $24 \mathrm{~h}$. Using a sliding microtome, $40-\mu \mathrm{m}$-thick frozen coronal sections were collected in $0.1 \mathrm{M}$ PBS.

Immunohistochemistry. Sections were washed in PBS and then incubated in a blocking solution (10\% normal goat serum, $1 \%$ BSA, $0.2 \%$ cold fish gelatin, and $0.2 \%$ Triton X-100 in PBS) for $1 \mathrm{~h}$ at room temperature. Sections were then incubated in primary antibodies in a diluted (1:10) blocking solution overnight at $4^{\circ} \mathrm{C}$, washed in PBS four times for 5 min each time and $1 \mathrm{~h}$ of secondary antibody incubation at room temperature, followed by PBS washes four times for 5 min each time. Nuclear counterstaining was performed with $100 \mathrm{ng} / \mathrm{ml} \mathrm{4,6-diamidino-2-phenylindole}$ (DAPI) solution in water for $10 \mathrm{~min}$. Primary antibodies were used in the following concentrations: mouse anti-parvalbumin (1:1000; SigmaAldrich), rat anti-somatostatin (1:500; Millipore Bioscience Research Reagents), rabbit anti-somatostatin (1:1000; Millipore Bioscience Research Reagents), rat anti-PDGFR (platelet-derived growth factor receptor) (1:500; BD Biosciences Pharmingen), rabbit anti-neuropeptide Y (1:500; Incstar), sheep anti-neuropeptide Y (1:500; Abcam), rabbit anti-vasoactive intestinal polypeptide (1:500; Incstar), rabbit anti-calretinin (CR) (1:1000; Millipore Bioscience Research Reagents), mouse anti-calretinin (1:1000; Millipore Bioscience Research Reagents), mouse anti-reelin (1:500; MBL), mouse anti-cholecystokinin (1:1500; Sigma-Aldrich), rabbit anti-SatB2 (1:1000; Abcam), rat anti-enhanced green fluorescent protein (EGFP) (1:2000; Nacalai Tesque), and rabbit anti-Olig2 (1:1000; Millipore Bioscience Research Reagents). Secondary antibodies conjugated with Cy3, and Cy5 (1:200; Jackson ImmunoResearch) or Alexa Fluor dyes 488 and 594 (1:1000; Invitrogen) were used to visualize the signals. Fluorescent images for cell counting were taken using a Zeiss LSM 510 META confocal microscope.

Double in situ hybridization. Sections were dried for $1 \mathrm{~h}$ before $10 \mathrm{~min}$ fixation in 4\% PFA. After wash, endogenous peroxidase activity was quenched by $1.5 \% \mathrm{H}_{2} \mathrm{O}_{2}$ in methanol for $15 \mathrm{~min}$ at room temperature. Sections were then treated in $0.2 \mathrm{M} \mathrm{HCl}$ for $8 \mathrm{~min}$ before a proteinase $\mathrm{K}$ treatment ( $10 \mu \mathrm{g} / \mathrm{ml}$; Roche) for $3 \mathrm{~min}$ and a postfixation in $4 \%$ PFA for $10 \mathrm{~min}$ at $4^{\circ} \mathrm{C}$ with washing steps in between. Before hybridization, the tissue was acetylated in TEA (tetraethylammonium) $(0.185 \mathrm{~g} / \mathrm{ml}$; SigmaAldrich), $0.5 \mathrm{~N} \mathrm{NaOH}$, and $0.25 \%$ acetic anhydride (Sigma-Aldrich). The digoxigenin (DIG)- and FITC-labeled probes (full-length cDNA probes of Gad67, PV, SST, EGFP, and 5HT3aR) were mixed $2 \mu$ l per slide in 250 $\mu l$ of hybridization buffer ( $50 \%$ formamide, $10 \%$ dextrane sulfate, 0.25 $\mathrm{mg} / \mathrm{ml}$ yeast RNA, $0.3 \mathrm{~m} \mathrm{NaCl}, 20 \mathrm{~mm}$ Tris, 5 mм EDTA, $10 \mathrm{~mm} \mathrm{NaPO}_{4}$, and $1 \% n$-lauroylsarcosine in Denhardt's solution) and denatured at $80^{\circ} \mathrm{C}$ for $2 \mathrm{~min}$. Hybridization was made overnight at $55^{\circ} \mathrm{C}$. After hybridization, the sections was rinsed in a $2 \times$ SSC with $50 \%$ formamide solution for $30 \mathrm{~min}$ at $65^{\circ} \mathrm{C}$ before several washes in RNase buffer $(0.5 \mathrm{M}$ $\mathrm{NaCl}, 10 \mathrm{~mm}$ Tris, $\mathrm{pH} 7.5$, and $5 \mathrm{~mm}$ EDTA, $\mathrm{pH}$ 8.0). The tissue was treated with RNase ( $20 \mu \mathrm{g} / \mathrm{ml}$; Roche) in RNase buffer for 30 min at $37^{\circ} \mathrm{C}$ before rinsing in decreasing amounts of SSC $(2 \times, 0.2 \times$, and $0.1 \times)$ for 15 min at $37^{\circ} \mathrm{C}$ each. After equilibrating in TN buffer $(0.1 \mathrm{M}$ Tris, $\mathrm{pH} 7.5$, and $0.15 \mathrm{M} \mathrm{NaCl}$ ), the sections were blocked in $0.5 \%$ blocking reagent (Roche) in TN buffer for $30 \mathrm{~min}$ at room temperature. The sections were then incubated with primary antibody against FITC or DIG (whichever is the weakest probe) overnight at $4^{\circ} \mathrm{C}$. On the third day, sections were rinsed in TNT buffer (TN buffer with $0.05 \%$ Tween 20 ) before amplification and visualization step using the TSA Plus Cyanine 3/Fluorescein System (PerkinElmer) according to the manufacturer's instruction (10-60 min incubation). After washes in TNT, the peroxidase was quenched in $3 \% \mathrm{H}_{2} \mathrm{O}_{2}$ in $\mathrm{TN}$ for $2 \mathrm{~h}$ at room temperature before incubation with the other primary antibody for $1 \mathrm{~h}$ at room temperature followed by visualization using the same kit as above. After washes in TNT, sections were incubated in DAPI before mounting in Fluoromount-G. Images were obtained by fluorescent microscopy on a Zeiss Axioskop using Spot Advanced software and/or by confocal microscopy using a Zeiss LSM 510 Meta system.

Slice preparation for electrophysiology. All procedures were conducted in accordance with the National Institutes of Health Guide for the Care and Use of Laboratory Animals. The $5 H T 3 a R-B A C^{E G F P}$ transgenic mouse line was provided by GENSAT. Mice (14-21 d of age) were anesthetized with intraperitoneal injection of pentobarbital ( $100 \mathrm{mg} / \mathrm{kg}$ body weight) and decapitated. The brain was quickly removed and immersed in icecold oxygenated artificial CSF (ACSF) containing the following (in mM): $125 \mathrm{NaCl}, 26 \mathrm{NaHCO}_{3}, 2.5 \mathrm{KCl}, 1.25 \mathrm{NaH}_{2} \mathrm{PO}_{4}, 2 \mathrm{CaCl}_{2}, 2 \mathrm{MgCl}_{2}$, and 10 glucose. Coronal slices $(300 \mu \mathrm{m})$ were made using Vibratome 1000 Plus (Vibratome), incubated at room temperature in ACSF for $1 \mathrm{~h}$ before recording. For thalamocortical recording, TC slices $(400 \mu \mathrm{m})$ were prepared from mice aged postnatal day 14 (P14) to P17, as previously described (Agmon and Connors, 1991; Kruglikov and Rudy, 2008). The ACSF solution was continuously equilibrated with $95 \% \mathrm{O}_{2}$ and $5 \% \mathrm{CO}_{2}$ throughout cutting, slice incubation, and recording.

Electrophysiological recordings. Whole-cell current-clamp recordings were performed using micropipettes (3-6 M $\Omega$ ) filled with internal solution containing the following (in $\mathrm{mm}$ ): $135 \mathrm{~K}$-gluconate, $4 \mathrm{KCl}, 2 \mathrm{NaCl}$, 10 HEPES, 0.2 EGTA, 4 ATP-Mg, 0.3 GTP-Tris, 1.4 phosphocreatineTris, $\mathrm{pH} 7.25,280 \mathrm{mOsm}$, and biocytin. Membrane potentials reported here were not corrected for the liquid junction potential. Recordings were conducted at $29-32^{\circ} \mathrm{C}$. When patching, cell-attached seal resistances were $>1 \mathrm{G} \Omega$ and series resistance after achieving whole-cell configuration was between 5 and $25 \mathrm{M} \Omega$. A series of hyperpolarizing and depolarizing step currents were injected to measure intrinsic properties of each neuron. Data were collected using an Axopatch 200B amplifier (Molecular Devices), low-pass filtered at $5 \mathrm{kHz}$, digitized at 16-bit resolution (Digidata 1322A; Molecular Devices), and sampled at $20 \mathrm{kHz}$. pCLAMP 9 software (Molecular Devices) was used for data acquisition, and analysis was performed using the Clampfit module of pCLAMP. For TC recording, bipolar stimulating electrodes were placed at the border of the ventrobasal (VB) nucleus of the thalamus, and brief current pulses $(20 \mathrm{~Hz})$ with increasing intensity were delivered while performing simultaneous whole-cell recordings from neurons in deep L3 and L4 of barrel cortex. To visualize the recorded neurons, slices were fixed for overnight with $4 \%$ paraformaldehyde in PBS, rinsed with PBS, and incubated in a 
blocking solution ( $1 \%$ normal goat serum and $0.3 \%$ Triton $\mathrm{X}-100, \mathrm{pH} 7.5$, in PBS) for $2 \mathrm{~h}$. After several washes with PBS, biocytin-filled neurons were stained using streptavidinconjugated Alexa Fluor 555 (1:500 dilution; Invitrogen). Fluorescently labeled neurons were imaged and reconstructed using a Zeiss LSM 510 META confocal microscope and Neurolucida software (MicroBrightField).

Electrophysiological analysis. To characterize the intrinsic membrane properties of neurons, hyperpolarizing and depolarizing current steps of $500 \mathrm{~ms}$ duration were applied in $1-20 \mathrm{pA}$ increments at $0.2 \mathrm{~Hz}$ as described previously (Miyoshi et al., 2010). The following parameters were measured: resting membrane potential (RMP) (in millivolts): the stable membrane potential reached a few minutes after breaking the membrane with no holding current applied; input resistance $\left(R_{\mathrm{m}}\right)$ (in megaohms): the slope of the regression line fitted to the $I-V$ curve (usually between -50 and $-10 \mathrm{pA}$ ), as measured at the end of the $500 \mathrm{~ms}$ voltage responses; membrane time constance $(\tau)$ (in milliseconds): determined from the monoexponential curve best fitting to the average voltage response to hyperpolarizing current steps of -40 to $-20 \mathrm{pA}$ using fitting function in Clampfit 9 (Molecular Devices); delay to spike (in milliseconds): time to first spike from the beginning of current injection; spike threshold (in millivolts): the membrane potential at the point at which the interpolated rate of voltage rise $(d V / d t)$ reached $>10 \mathrm{mV} / 1 \mathrm{~ms}$; spike height (in millivolts): action potential amplitude, measured from the threshold to the peak; spike width (in milliseconds): action potential duration, the spike width at its half-amplitude; afterhyperpolarization (AHP) (in millivolts): peak amplitude of the AHP, measured from the spike threshold; tAHP (in milliseconds): AHP latency, the time interval between spike threshold and the hyperpolarization nadir; maximum firing frequency (in hertz): spike frequency in response to 20 times of rheobase current step; adaptation: frequency adaptation, percentage of decrease in the frequency from first $100 \mathrm{~ms}$ to last $100 \mathrm{~ms}$.

\section{Results}

Interneuron-specific expression of $5-\mathrm{HT}_{3 \mathrm{~A}} \mathrm{R}$ in the mouse cortex We used a mouse line expressing EGFP under the control of the $5 H \operatorname{tr} 3 a R$-promoter $\left(5 H T 3 a R-B A C^{E G F P}\right)$ provided by the GENSAT project at Rockefeller University. To assess whether $5 H T 3 a R-B A C^{E G F P}$-driven EGFP expression reflects true $5 \mathrm{Htr} 3 a$ gene transcription, we performed double in situ hybridization (ISH) for EGFP and $5 H T 3 a R$ mRNA. We found near complete overlap between the EGFP and the 5HT3aR signals, indicating that EGFP expression is indeed specific to cells expressing $5-\mathrm{HT}_{3 \mathrm{~A}} \mathrm{Rs}$ and that virtually all 5- $\mathrm{HT}_{3 \mathrm{~A}} \mathrm{R}$-expressing neurons express EGFP (99.8 \pm $0.3 \%$ ) (Fig. $1 \mathrm{~A}$ ). We also performed double in situ hybridization for EGFP and Gad67. All cells that expressed EGFP also expressed Gad67 mRNA, indicating that at the age tested (P21) $5-\mathrm{HT}_{3 \mathrm{~A}} \mathrm{R}$ expression is confined to a GABAergic population (Fig. $1 B$ ). This conclusion was further strengthened by the complete lack of overlap between EGFP and the pyramidal cell marker Satb2 or the oligodendrocyte marker Olig2 by immunohistochemistry (Fig. 1C,D) (Lu et al., 2000; Zhou and Anderson, 2002; Britanova et al., 2008).

\section{5-HT ${ }_{3 \mathrm{~A}} \mathrm{R}$-expressing neurons constitute the third major} group of interneurons and are densely present in superficial layers

Previous studies have shown that interneurons expressing the $5-\mathrm{HT}_{3 \mathrm{~A}}$ R include neurons containing VIP, CR, and NPY, but not PV

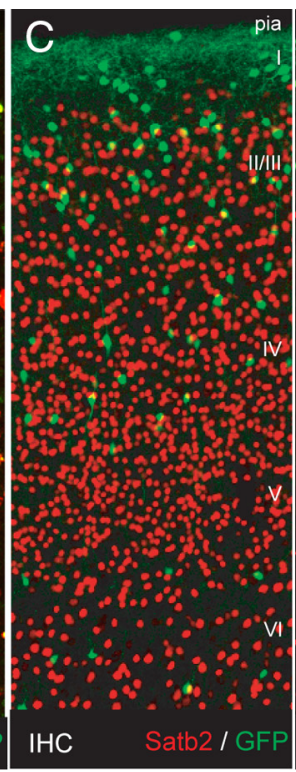

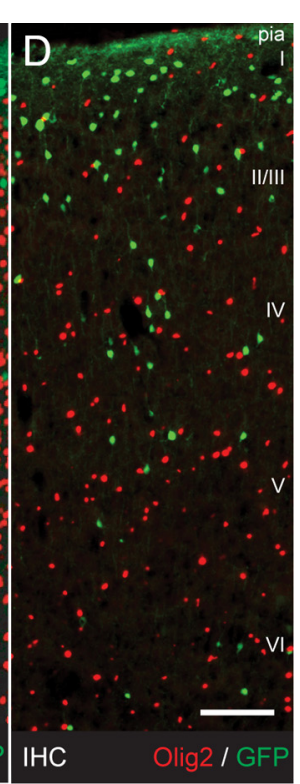

$\mathrm{HC}$
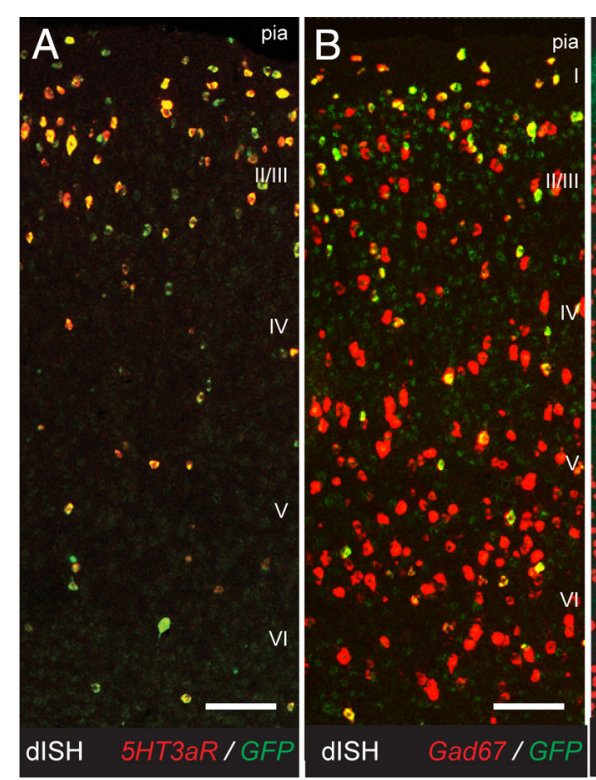

Figure 1. $5 H T 3 a R-B A C C^{E G F P}$ cells of the somatosensory cortex are $5-H T_{3 A} R$-expressing GABAergic interneurons. $A, B$, Double in situ hybridization for 5HT3aR and EGFP/GAD67. A, Double in situ for 5HT3aR and EGFP show complete overlap in the adult somatoverlap with pyramidal cell marker Satb2 confirms the interneuron identity. $\boldsymbol{D}$, No EGFP-positive cells express oligodendrocyte dISH, Double in situ hybridization; IHC, immunohistochemistry.

or SST (Férézou et al., 2002; Inta et al., 2008; Vucurovic et al., 2010). Consistent with this, we detect no, or nearly no, overlap between PV or SST and GFP expression in the 5HT3aR-BAC EGFP mouse, respectively (see Fig. 4). To elucidate the population of $5-\mathrm{HT}_{3 \mathrm{~A}} \mathrm{R}$ expressing neurons and determine its contribution to the total interneuron population, we used double in situ hybridization to determine the proportion and layer distribution of Gad67-expressing neurons that express $5-\mathrm{HT}_{3 \mathrm{~A}} \mathrm{R}$ and compared this to the PV- and SST-expressing populations. We also performed double ISH for PV and SST to determine the overlap of the mRNA of these two markers (Fig. $2 A-C$, quantified in $D$ ). We first analyzed the laminar distribution of $5-\mathrm{HT}_{3 \mathrm{~A}} \mathrm{R}$-expressing neurons (Fig. $2 \mathrm{D}$ ) and found that more than two-thirds of these cells have cell bodies positioned within superficial layers of Gad67-expressing neurons (L1, $15 \pm 0.3 \%$; L2/3, $54 \pm 0.6 \%$ ). Within layers 1 , and $2 / 3$, the number of $5-\mathrm{HT}_{3 \mathrm{~A}} \mathrm{R}-$ expressing neurons exceeds the number of PV-positive neurons by more than twofold, indicating that the major type of GABAergic interneuron in superficial layers of the cortex is the $5-\mathrm{HT}_{3 \mathrm{~A}} \mathrm{R}$ expressing population. Furthermore, by combining the results from the four different in situ hybridizations, we find that with the possible exception of $\sim 5 \%$ of neurons in layer I, we can ascribe every GABAergic neuron in somatosensory neocortex to one of three groups expressing PV, SST, or $5-\mathrm{HT}_{3 \mathrm{~A}} \mathrm{R}$. The deviation from $100 \%$ in Figure $2 D$ was caused by the cumulative variation resulting from combining the four different double in situ hybridization experiments. We conclude that the $5-\mathrm{HT}_{3 \mathrm{~A}} \mathrm{R}$-expressing cells not only primarily populate superficial layers, but are in fact the predominant population of interneurons within this region. More importantly, collectively PV, SST, or $5-\mathrm{HT}_{3 \mathrm{~A}} \mathrm{R}$ labeling account for nearly $100 \%$ of all GABAergic interneurons.

A majority of 5- $\mathrm{HT}_{3 \mathrm{~A}} \mathrm{R}$-expressing cells are derived from the caudal ganglionic eminence

Given the 5HT3aR-BAC ${ }^{E G F P}$ expression was restricted to non-PV/ SST interneurons in mature animals, we set out to determine the site(s) of origin of this population. Cortical interneurons are mainly 

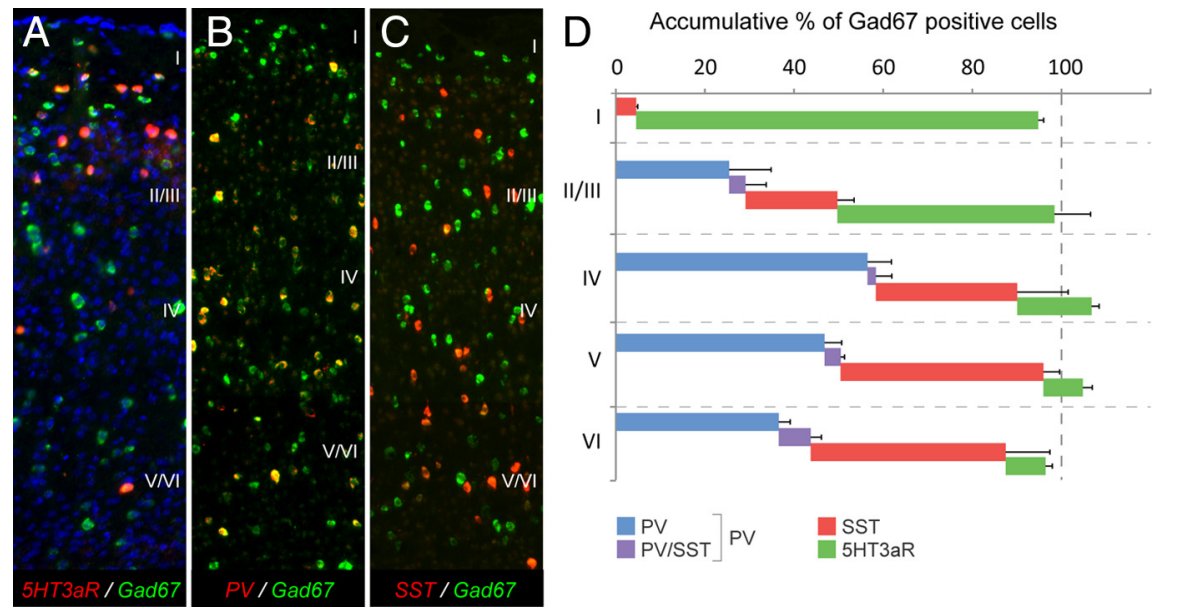

Figure 2. $\quad 5-\mathrm{HT}_{3 \mathrm{~A}} \mathrm{R}$-expressing cells are the third major group of cortical interneurons. $\mathrm{A}-\mathrm{C}$, Double in situ hybridization (dISH) for the three markers PV, SST, and 5HT3aR with pan-GABAergic marker Gad67. D, Cumulative graph showing the percentage of Gad67 cells expressing each marker. Note that $100 \pm 5 \%$ of interneurons of all layers can be accounted for using these three markers and that $5-\mathrm{HT}_{3 \mathrm{~A}} \mathrm{R}$-expressing neurons predominantly occupy superficial layers. Notably we observed some overlap in the in situ signal between SST and PV even though this cannot be seen at the protein level. Error bars represent SEM.
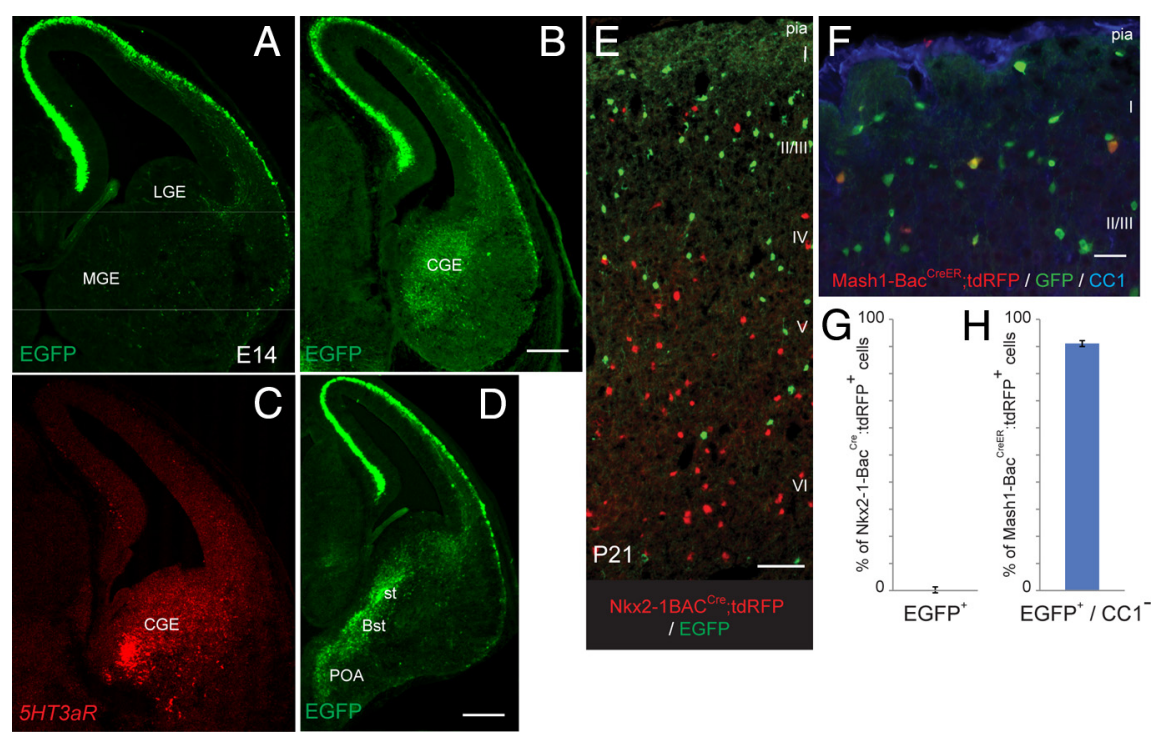

Figure 3. $A-D, 5 H T 3 a R-B A C^{E G F P}$ mice have labeled neurons in the CGE (as well as more ventral structures) but not the LGE or MGE. This EGFP expression reflects true 5HT3aR mRNA expression as shown by ISH for 5HT3aR (C). $\boldsymbol{E}-\boldsymbol{H}$, Genetic fate mapping confirms that 5- $\mathrm{HT}_{3 \mathrm{~A}} \mathrm{R}$-expressing cells in mature cortex are CGE derived. We used Nkx2.1-BAC $C^{\mathrm{Cre}}$ and Mash 1-BAC ${ }^{\mathrm{CreER}}$, mouse lines in combination with the R26R ${ }^{\text {tdRFP }}$-reporter crossed on to the 5HT3aR-BA ${ }^{E G F P}$ to label cells embryonically and follow their fate into the mature cortex. $\mathbf{G}, \boldsymbol{H}$, The complete lack of Nkx2.1-BAC ${ }^{C e} ; R 26 R^{\text {tdRFP }}$ and $5 H T 3 a R-B A C^{E G F P}$ overlap shows that the cells are not of MGE origin, whereas the almost complete overlap with Mash1-BAC ${ }^{C r e E R} ; R 26 R^{\text {tdRFP }}$-labeled interneurons confirms the CGE origin. CC1 was used as a marker to exclude RFP-expressing oligodendrocytes from quantization $(\boldsymbol{H})$. Scale bars: $\boldsymbol{B}, \boldsymbol{D}, 250 \mu \mathrm{m} ; \boldsymbol{E}, 100 \mu \mathrm{m}$; $F, 50 \mu \mathrm{m}$. Error bars represent SD.

derived from two different ventral progenitor zones, the CGE and MGE, respectively (Anderson et al., 1997a,b; Wichterle et al., 1999, 2001; Nery et al., 2002; Butt et al., 2005). 5Htr3aR-BAC ${ }^{E G F P}$ animals examined at all embryonic time points (beginning at E12) had EGFP expression within the CGE but not in the MGE/LGE (Fig. 3A,B). Furthermore, there was an extension of the expression into the stria terminalis and the preoptic area (POA), a region that has been shown to give rise to a small subset of cortical interneurons (Gelman et al., 2009). In situ hybridization analysis for $5 H T 3 a R$ at these time points yielded similar results (Fig. 3C). In agreement with previous findings, we also observed extensive EGFP expression by preplate neurons including Cajal-Retzius cells (Fig. 3A,B) (Inta et al., 2008;
Chameau et al., 2009). Since the expression of the $5-\mathrm{HT}_{3 \mathrm{~A}} \mathrm{R}$ may be dynamic, we set out to investigate whether the cells expressing $5-\mathrm{HT}_{3 \mathrm{~A}} \mathrm{R}$ embryonically are the same cells expressing it in the adult. To this end, we used two different genetic fate-mapping strategies (Xu et al., 2008; Miyoshi et al., 2010) to investigate from which zone the cortical EGFP-labeled cells were derived. Using the Nkx2.1-BAC ${ }^{C r e}$ mouse together with the red $R 26 R^{t d R F P}$ reporter mouse (Luche et al., 2007), we labeled cells originating from the MGE. When these mice were crossed onto the 5HT3aR-BAC ${ }^{E G F P}$ mice, we saw no overlap between EGFP and tandem-dimer red fluorescent protein (tdRFP) expression, indicating that the $5-\mathrm{HT}_{3 \mathrm{~A}} \mathrm{R}$-expressing cells in mature cortex are not derived from the MGE (Fig. $3 E$, quantified in $G$ ). We have recently shown that one can efficiently label cells derived from the CGE using a Mash1-BAC CreER mouse to direct the tamoxifen-induced crerecombination of a reporter line (Miyoshi et al., 2010). We used the Mash1-BAC ${ }^{\text {CreER }}$ mouse together with the $R 26 R^{\text {tdRFP }}$ reporter to confirm that $5-\mathrm{HT}_{3 \mathrm{~A}} \mathrm{R}$-expressing neurons originate from the CGE. Although neuronal labeling was most prominent, we observed some tdRFP expression within oligodendrocytes. The immunohistochemical marker CC1 was used to exclude these cells from the analysis (Bhat et al., 1996). We observed a $91 \pm 1 \%$ overlap between interneurons derived from a tamoxifen-induced E16.5 labeling of the Mash1-BAC $C^{\text {CreER }}$; $R 26 R^{\text {tdRFP }}$ and the 5HT3aR-BAC $C^{E G F P}{ }_{-}$ driven EGFP expression, showing that $5-\mathrm{HT}_{3 \mathrm{~A}}$-expressing cells are derived from the CGE and not from the MGE (Fig. $3 F$, quantified in $H$ ). This was also true at earlier gavage points (data not shown).

\section{Neurochemical profile of}

\section{5-HT ${ }_{3 \mathrm{~A}} \mathrm{R}$-expressing neurons}

According to our ISH analysis, $5-\mathrm{HT}_{3 \mathrm{~A}} \mathrm{R}$ interneurons compromise $28.8 \pm 2.2 \%$ of the neurons in somatosensory cortex that express the pan-GABAergic marker Gad67. To parse out the 5- $\mathrm{HT}_{3 \mathrm{~A}} \mathrm{R}$ population in this region in more detail, we analyzed their expression of a variety of neurochemical interneuron markers (Ascoli et al., 2008). Although some molecular markers may not precisely correlate with different interneuron subtypes, their expression does provide a strong indicator of their anatomical and electrophysiological properties. We used as markers two calcium-binding proteins (PV and CR), and four neuropeptides (SST, CCK, VIP, and NPY), all which are exclusively expressed in GABAergic interneurons in neocortex (Fig. $4 A-F$ ). In addition to these six markers, we also examined the expression of reelin, which was recently reported as a marker of GABAergic neurons (Miyoshi et al., 2010). Reelin is expressed in subpopulations of both MGE- and CGE-derived interneurons, but all MGE-derived 


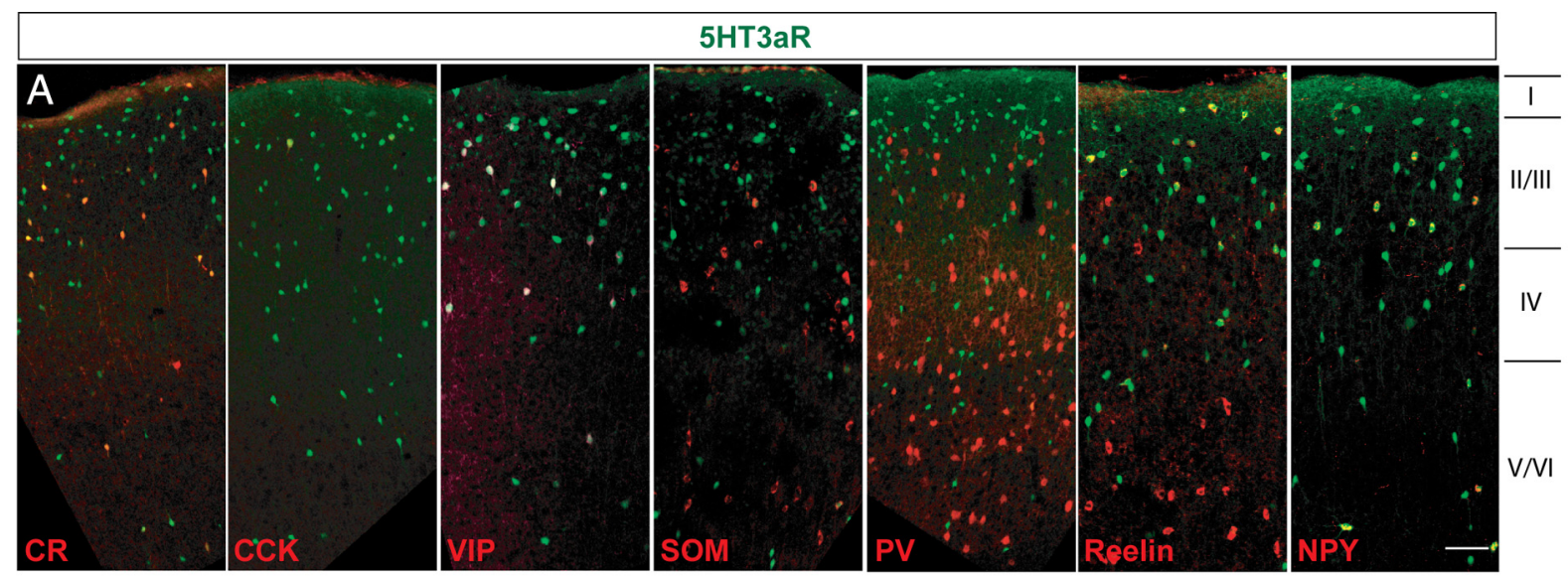

B

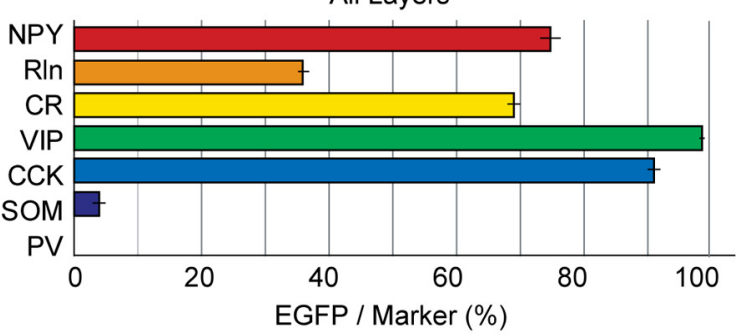

C

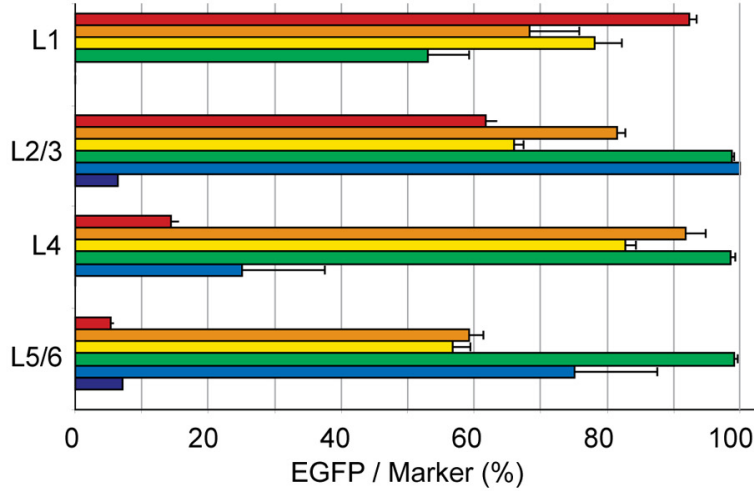

D

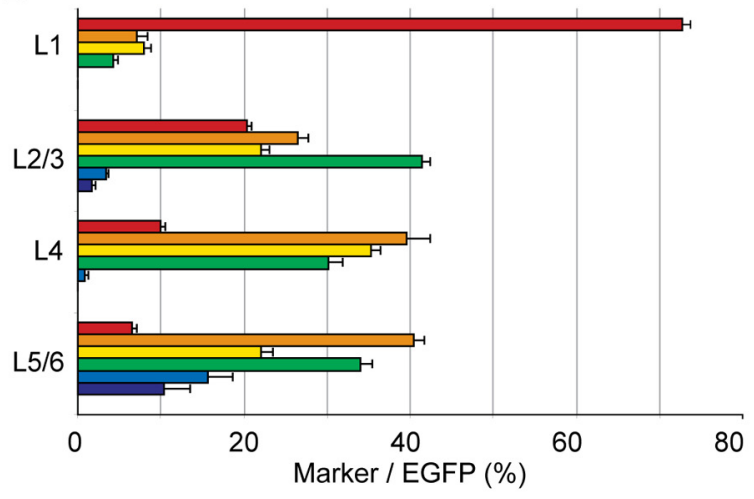

$\mathrm{E}$

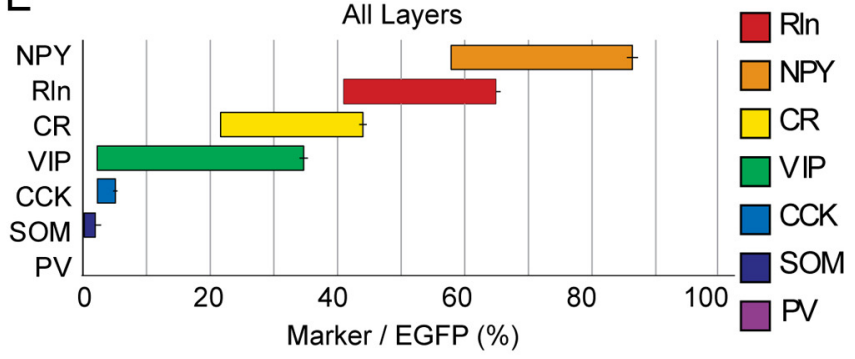

$\mathrm{F}$
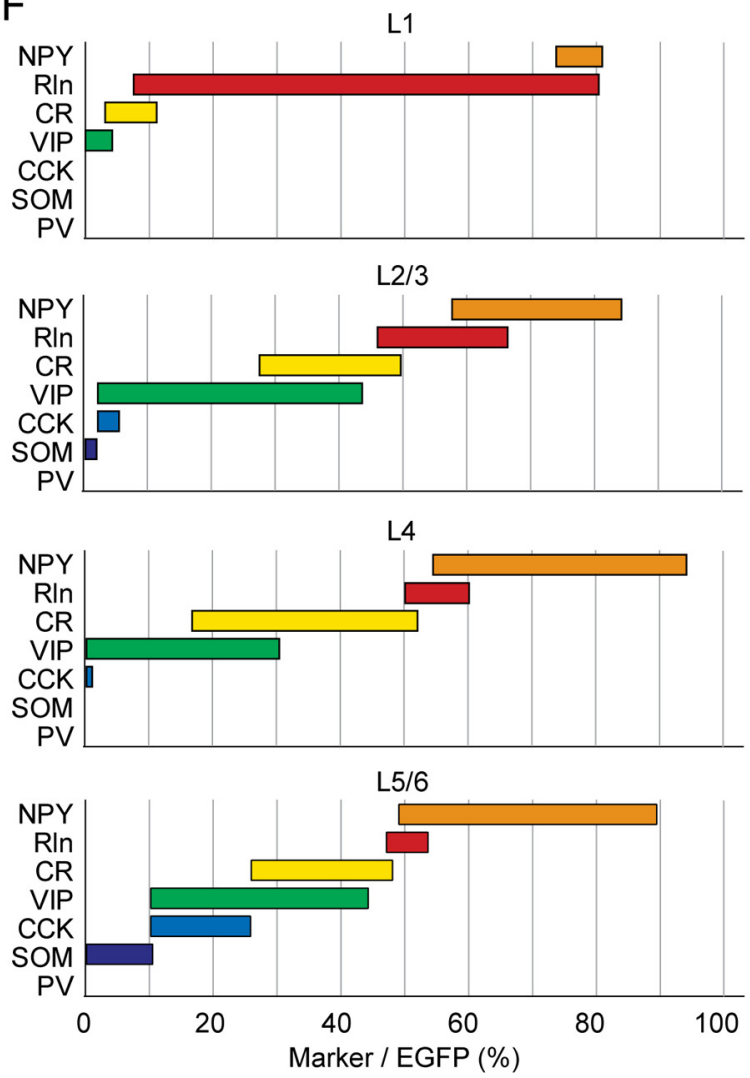

Figure 4. Neurochemical marker expression profiles of $5-\mathrm{HT}_{3 \mathrm{~A}} \mathrm{R}$-expressing cortical interneurons. $\boldsymbol{A}$, Immunofluorescent histochemistry show the relationship of seven neuronal markers (CR, CCK, VIP, SST, PV, RIn, and NPY) and 5-HT $3 A$ R-positive neurons in somatosensory cortex (P21-P25) of 5HT3aR-BAC ${ }^{E G P}$ mice $(n=3)$. B, The percentage of specific neuronal markers that is also positive for EGFP across all layers (EGFP/marker). $\boldsymbol{C}$, Same as in $\boldsymbol{B}$ but analyzed per layer. $\boldsymbol{D}$, The percentage of 5 - $\mathrm{HT}_{3 \mathrm{~A}} \mathrm{R}$-expressing neurons expressing specific neuronal markers per individual layers (marker/EGFP). $\boldsymbol{E}$, The proportion of $5-\mathrm{HT}_{3 \mathrm{~A}} \mathrm{R}$-expressing neurons expressing specific neuronal markers across all layers (marker/EGFP), individual bars are displaced to illustrate the overlap caused by colocalization of markers. $\boldsymbol{F}$, Same as $\boldsymbol{E}$ but analyzed per layer. Note that $>85 \%$ of 5 - $\mathrm{HT}_{3 \mathrm{~A}} \mathrm{R}$-expressing neurons were found to express at least one of the seven neuronal markers. RIn, Reelin; NPY, neuropeptide Y; CR, calretinin; VIP, vasoactive intestinal peptide; CCK, cholecystokinin; SOM, somatostatin; PV, parvalbumin. Scale bar, $100 \mu \mathrm{m}$. Error bars represent SEM. 
reelin-positive cells appear to also express SST, suggesting that all reelin +/SST - cells are CGE derived. To accurately estimate the proportion of all $5-\mathrm{HT}_{3 \mathrm{~A}} \mathrm{R}$-expressing neurons expressing these seven neuronal markers, we also examined the degree of overlap of many of these markers in 5- $\mathrm{HT}_{3 \mathrm{~A}} \mathrm{R}$-expressing neurons, using double immunohistochemical analysis (Fig. 4E,F). With these markers, we were able to account for $>85 \%$ of the $5-\mathrm{HT}_{3 \mathrm{~A}} \mathrm{R}$ expressing neurons in the primary somatosensory cortex (Fig. $4 E$ ).

In agreement with previous findings and consistent with our in situ results, we never observed colocalization of $\mathrm{PV}$ with 5- $\mathrm{HT}_{3 \mathrm{~A}} \mathrm{R}$-positive neurons (Férézou et al., 2002; Inta et al., 2008; Vucurovic et al., 2010). Moreover, $<3 \%$ of $5-\mathrm{HT}_{3 \mathrm{~A}} \mathrm{R}$-expressing neurons were found to express SST (Fig. $4 E$ ). The finding that $5-\mathrm{HT}_{3 \mathrm{~A}} \mathrm{R}$-expressing neurons do not express these MGE-derived interneuron markers is also consistent with the results from the fate mapping (Fig. 3E). Notably, nearly all VIP- and or CCKpositive neurons expressed $5-\mathrm{HT}_{3 \mathrm{~A}} \mathrm{R}$ as well as a majority of NPY-expressing cells (Fig. 4C). NPY is reportedly found in SST(Wonders and Anderson, 2006) as well as in PV-expressing populations (Karagiannis et al., 2009). This result is consistent with previous findings that $5-\mathrm{HT}_{3 \mathrm{~A}} \mathrm{R}$ was detected in GABAergic interneurons coexpressing CCK and VIP in both cortex and hippocampus (Morales and Bloom, 1997; Férézou et al., 2002; Vucurovic et al., 2010). We find that reelin and CR partially overlap with SST (Pesold et al., 1999; Miyoshi et al., 2010), and therefore only a fraction of the reelin and CR populations expressed $5-\mathrm{HT}_{3 \mathrm{~A}} \mathrm{R}$ (Fig. $4 \mathrm{~B}, \mathrm{C}$ ). We also analyzed the layer distribution of these markers within the $5-\mathrm{HT}_{3 \mathrm{~A}} \mathrm{R}$-expressing population (Fig. $4 C, D, F)$. Reelin was expressed by a large majority $(73.0 \pm 4.0 \%)$ of 5- $\mathrm{HT}_{3 \mathrm{~A}} \mathrm{R}$-expressing neurons in L1 (Fig. $4 \mathrm{D}$ ). The proportion $5-\mathrm{HT}_{3 \mathrm{~A}} \mathrm{R}$ cells expressing NPY was highest in deeper layers ( $40 \pm$ $7.5 \%$ of EGFP-positive cells in L4 and $40 \pm 3.5 \%$ in L5/6) (Fig. $4 D)$. Conversely, in layers $2 / 3$ and 4 , most NPY cells are $5-\mathrm{HT}_{3 \mathrm{~A}} \mathrm{R}$ positive ( $82 \pm 4$ and $92 \pm 8.5 \%$, respectively), whereas only $\sim 60 \%$ of NPY cells in layer $5 / 6$ express the $5-\mathrm{HT}_{3 \mathrm{~A}} \mathrm{R}$ (Fig. $4 \mathrm{C}$ ).

\section{Intrinsic electrophysiological properties of $5-\mathrm{HT}_{3 \mathrm{~A}} \mathrm{R}-$ expressing neurons}

To examine the electrophysiological and morphological profile of 5- $\mathrm{HT}_{3 \mathrm{~A}} \mathrm{R}$-expressing neurons, we performed whole-cell recordings from EGFP-expressing neurons $(n=132)$ in superficial layers of the primary somatosensory cortex using an acute slice preparation (Fig. 5). Cells were recorded in current clamp and $500 \mathrm{~ms}$ hyperpolarizating and depolarizating steps were used to assess their intrinsic membrane properties, whereas biocytin was added in the recording pipette to allow for post hoc morphologi$\mathrm{cal}$ analysis. Based on their intrinsic membrane properties, as well as morphology, we classified the $5-\mathrm{HT}_{3 \mathrm{~A}} \mathrm{R}$-expressing neurons according to previously described criteria (Miyoshi et al., 2010). Miyoshi et al. (2010) described nine different types of CGEderived interneurons; here, we observed all except two of the rarest types [delayed intrinsic bursting (dIB) and sigmoid intrinsic bursting (sIB)]. This included two different late-spiking subtypes (LS1, 34.6\%; LS2, 11.3\%) (Kawaguchi, 1995; Chu et al., 2003; Tamás et al., 2003; Miyoshi et al., 2007; Oláh et al., 2007), bipolar/bitufted irregular spiking cells (IS, 22.5\%) (Cauli et al., 1997, 2000; Porter et al., 1998; Galarreta et al., 2004), the "arcade axon" delayed non-fast-spiking (dNFS3, 2.2\%) (Kawaguchi and Kubota, 1996; Butt et al., 2005), the fast-adapting cells (fAD, 12.0\%) (Butt et al., 2005), as well as burst nonadapting cells (bNA1, 13.5\%; bNA2, 3.7\%) (Kawaguchi and Kubota, 1996, 1997; Rozov et al., 2001; Butt et al., 2005; Caputi et al., 2009).
Late-spiking cells, LS1 and LS2, were characterized by a long delay with a steady ramp depolarization leading up to the initial spike at threshold current injections. Miyoshi et al. (2010) showed that both of these types express reelin but have significantly different electrophysiological and morphological properties. Electrophysiologically, LS1 is distinguished from LS2 in that the delay persists even when up to three to five spikes are induced during just suprathreshold current injection steps, whereas LS2 cells never show a pronounced delay when more than one spike is elicited. Both cell types showed firing frequency adaptation and nonmonotonic spike amplitude accommodation. LS1 possess a small soma and have locally ramifying short thin dendrites and a dense local axonal plexus. Thus, their morphology is similar to previously described cortical neurogliaform cells (Kawaguchi, 1995; Tamás et al., 2003; Miyoshi et al., 2007; Oláh et al., 2007). Similar to the description by Miyoshi et al. (2010), we found that LS2 neurons had lower input resistance and maximum firing rate compared with LS1 cells (Table 1), and larger soma size and thicker, longer, but less branching dendrites. IS neurons showed irregular firing patterns during intermediate current steps and strong monotonic spike amplitude accommodation throughout suprathreshold current injections. Most IS neurons exhibited a bipolar/tripolar morphology and had axonal trees projecting toward deeper layers. 5- $\mathrm{HT}_{3 \mathrm{~A}} \mathrm{R}$-expressing interneurons with an IS firing pattern resembled those previously described as VIP- and CR-positive bipolar interneurons (Cauli et al., 1997, 2000; Porter et al., 1998; Galarreta et al., 2004; Miyoshi et al., 2010). Interestingly, we observed an irregular-spiking multipolar cell that was not described in the study by Miyoshi et al. (2010) (Fig. 5). This subtype appeared very similar to those cells described as derived from the Nkx5-1 ${ }^{\text {Cre }}$-labeled population from the POA (Gelman et al., 2009). Fast adapting cells (fAD) are characterized by their failure to fire throughout the $500 \mathrm{~ms}$ step during suprathreshold depolarization. This subtype has been suggested to be the largest VIP-positive CR-negative population (Porter et al., 1998; Miyoshi et al., 2010). The last major subtype we identified was the burst nonadapting (bNA1) subtype that exhibited bursts of two or three spikes, followed by regular spiking. The bNA1 cells have a distinct feature giving rise to a "hump" at the beginning of the 500 ms current injection during near-threshold steps.

In addition to the six subtypes described above (accounting for $94 \%$ of all 5 HTR3aR cells), we identified a second bursting nonadapting subtype (bNA2) with intrinsic properties and morphology similar to previously described CR- and VIP-expressing bipolarshaped interneurons (Kawaguchi and Kubota, 1996; Cauli et al., 1997; Rozov et al., 2001; Butt et al., 2005; Caputi et al., 2009). We also identified a small bipolar dNFS3 subtype that exhibits an "axon arcade" morphology, which has been reported to be VIP positive (Kawaguchi and Kubota, 1996). These results both confirm and extend our previous analysis and suggest that 5HT3R neurons include both CGE (the large majority) and most likely the POA populations.

\section{Functional expression of $5-\mathrm{HT}_{3 \mathrm{~A}} \mathrm{Rs}$}

In the transgenic mouse line used in this study, expression of EGFP is driven by regulatory elements of the $5 \mathrm{Htr} 3 \mathrm{a}$ gene. We have shown that the EGFP signal accurately predicts the expression of $5 H T 3 a R$ mRNA, as detected by in situ hybridization. To confirm that this signal corresponds to the presence of functional receptors, we tested the effect of $m$-chlorophenyl-biguanide (mCPBG), a 5- $\mathrm{HT}_{3 \mathrm{~A}} \mathrm{R}$ selective agonist, on EGFP-positive neurons (Fig. 6A). We applied mCPBG $(100 \mu \mathrm{M})$ directly onto the soma of the recorded cell by puffing $(30 \mathrm{~ms})$ through a second patch pipette located $\sim 10 \mu \mathrm{m}$ away from the soma. mCPBG 

A LS1
LS2
bNA1
bNA2
IS
fAD
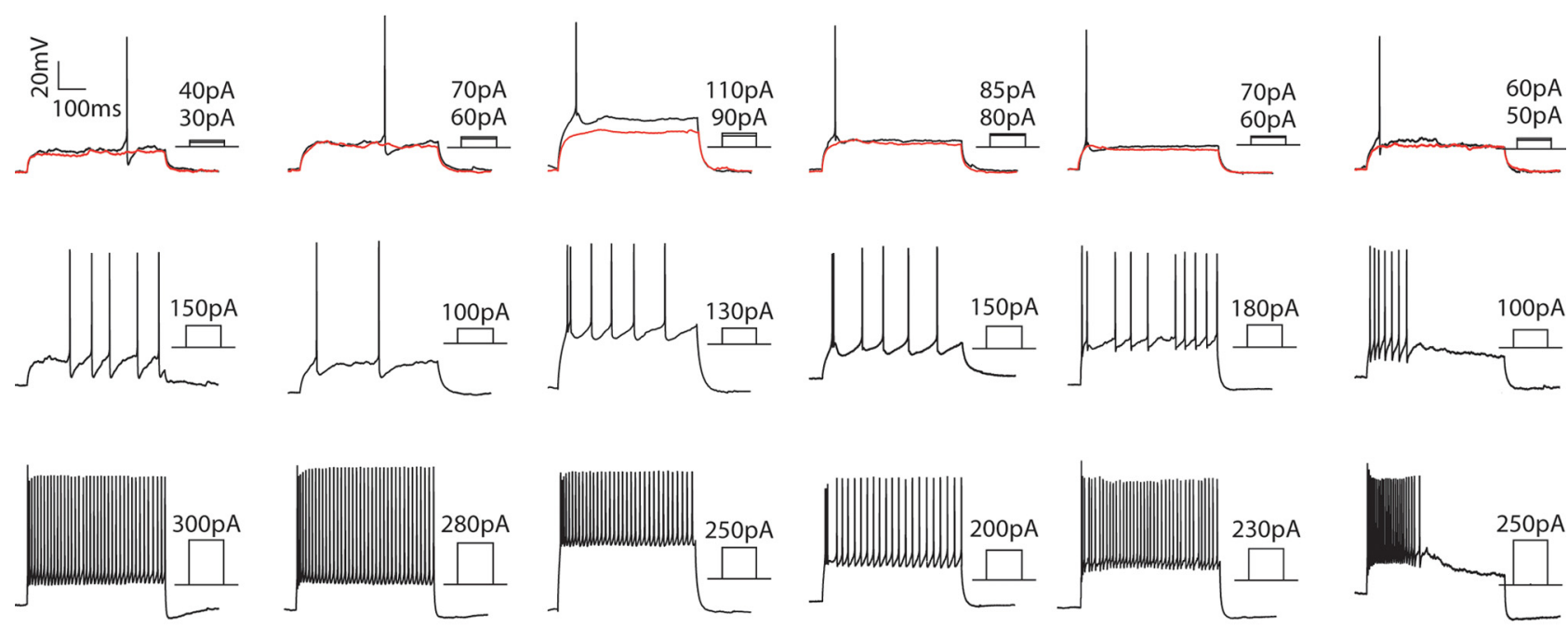

\section{B}

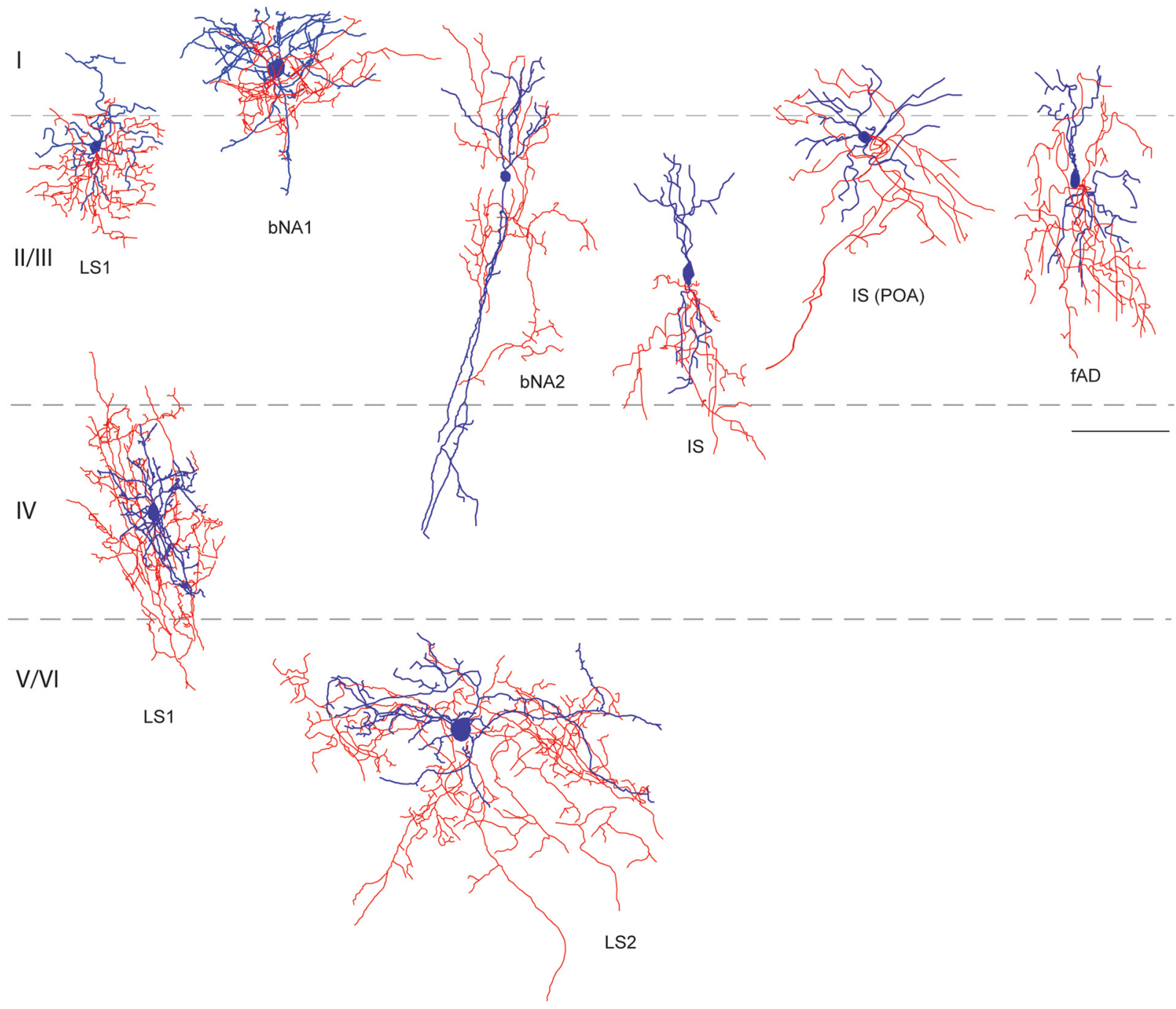

Figure 5. Intrinsic electrophysiological properties and morphologies of $5-\mathrm{HT}_{3 \mathrm{~A}} \mathrm{R}$-expressing cortical interneurons. $A$, Representative traces of voltage responses to $500 \mathrm{~ms}$ step current injection in current-clamp whole-cell configuration of six major subtypes of $5-\mathrm{HT}_{3 \mathrm{~A}} \mathrm{R}$ interneurons. $\boldsymbol{B}$, Examples of morphologies of different subtypes reconstructed using Neurolucida tracing. Dendrite and soma are shown in blue and axon in red. LS1, Late spiking 1; LS2, late spiking 2; bNA1, burst nonadapting 1; bNA2, burst nonadapting 2; IS, irregular spiking; fAD, fast adapting; POA, preoptic area. Scale bar, $100 \mu \mathrm{m}$. 
Table 1. Quantification of electrophysiological properties of 5-HT ${ }_{3 A} \mathrm{R}$-expressing neurons in layer $2 / 3(n=80)$

\begin{tabular}{|c|c|c|c|c|c|c|c|}
\hline & LS1 & LS2 & bNA1 & bNA2 & IS & dNFS3 & fAD \\
\hline $\mathrm{RMP}(\mathrm{mV})$ & $-61.2 \pm 5.8$ & $-60.5 \pm 7.0$ & $-63 \pm 4.3$ & $-60.2 \pm 5.7$ & $-58.4 \pm 5.9$ & $-65 \pm 6.3$ & $-56.9 \pm 7.0$ \\
\hline$R_{\mathrm{m}}(\mathrm{M} \Omega)$ & $329 \pm 89$ & $285 \pm 101$ & $332 \pm 124$ & $369 \pm 143$ & $406 \pm 132$ & $631 \pm 310$ & $459 \pm 179$ \\
\hline$\tau_{\mathrm{m}}(\mathrm{ms})$ & $17.3 \pm 6.5$ & $19.3 \pm 5.8$ & $17.5 \pm 8.5$ & $19.4 \pm 8.3$ & $20.1 \pm 7.1$ & $27.7 \pm 12.3$ & $26.4 \pm 9.7$ \\
\hline Spike threshold (mV) & $-38.2 \pm 5.4$ & $-36.9 \pm 5.1$ & $-35.5 \pm 4.5$ & $-36.1 \pm 3.8$ & $-39.8 \pm 6.3$ & $-42.2 \pm 6.1$ & $-38.3 \pm 4.9$ \\
\hline Spike width (ms) & $1.4 \pm 0.5$ & $1.4 \pm 0.4$ & $1.4 \pm 0.6$ & $1.4 \pm 0.4$ & $1.2 \pm 0.4$ & $1.3 \pm 0.3$ & $1.1 \pm 0.3$ \\
\hline AHP amplitude (mV) & $-19.3 \pm 5.2$ & $-18.2 \pm 3.9$ & $-16.1 \pm 5.1$ & $-14.4 \pm 4.6$ & $-13.0 \pm 0.4$ & $-15.3 \pm 3.3$ & $-12.2 \pm 3.4$ \\
\hline tAHP (ms) & $23.1 \pm 4.8$ & $24.8 \pm 7.9$ & $50.3 \pm 11.9$ & $24.9 \pm 8.5$ & $14.2 \pm 5.2$ & $14.1 \pm 9.8$ & $18.1 \pm 9.9$ \\
\hline Delay to spike (ms) & $376.3 \pm 79.8$ & $224.8 \pm 130.1$ & $70.3 \pm 21.4$ & $75.4 \pm 41.4$ & $259.5 \pm 120.5$ & $14.1 \pm 9.8$ & $18.1 \pm 9.9$ \\
\hline Max frequency $(\mathrm{Hz})$ & $79.3 \pm 30.1$ & $59.2 \pm 18.4$ & $52.6 \pm 14.9$ & $61.5 \pm 28.4$ & $84.9 \pm 16.5$ & $81.3 \pm 21.4$ & $85.7 \pm 21.5$ \\
\hline Adaptation (\%) & $51.3 \pm 14.5$ & $53.9 \pm 16.3$ & $63.7 \pm 18.2$ & $59.4 \pm 21.4$ & $41.5 \pm 11.6$ & $36.3 \pm 9.8$ & N/A \\
\hline
\end{tabular}

For an explanation of the parameters, see Materials and Methods.

A1
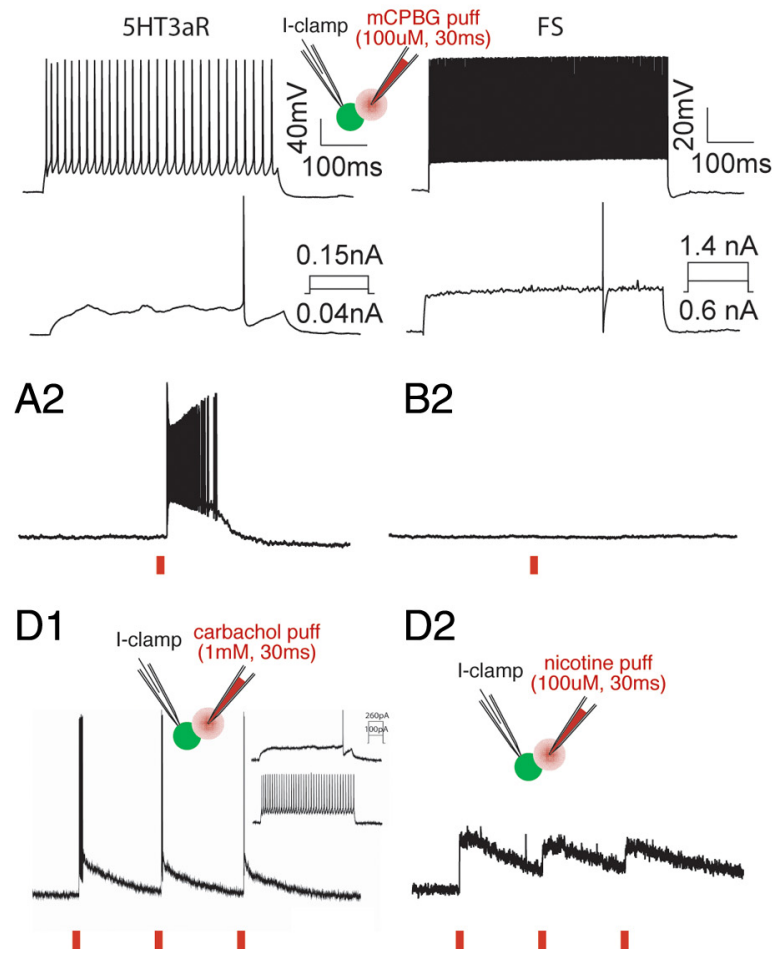

B2

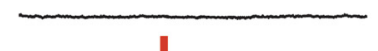

D2

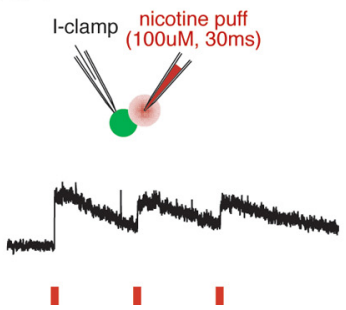

Figure 6. Functional expression of $5-\mathrm{HT}_{3 \mathrm{~A}} \mathrm{Rs}$ and $\mathrm{nAChRs}$ in $5-\mathrm{HT}_{3 \mathrm{~A}} \mathrm{R}$-expressing interneurons. Intrinsic firing patterns to step current injections recorded from three different types of cortical interneurons from 5HT3aR-BACGGP (A1), B13 (B1), and GIN (C1) transgenic mice. Application of a $5-\mathrm{HT}_{3 \mathrm{~A}} \mathrm{R}$ selective agonist (mCPBG; $100 \mu \mathrm{m} ; 30 \mathrm{~ms}$ puffing) causes strong depolarization and evokes a burst of spikes in $5-\mathrm{HT}_{3 \mathrm{~A}} \mathrm{R}$ cells ( $\boldsymbol{A}$ ) but not in $\mathrm{FS}$ ( $\boldsymbol{B 2}$ ) or SST-expressing cells (C2) ( 30 ms puffindicated by red line below). D, Functional expression of $n A C h$ receptors in EGFP-positive neurons of $5 H T 3 a R-B A{ }^{E G F P}$ mouse. D1, Carbachol application (1 mM) strongly depolarizes and evokes burst of spikes in a $5-\mathrm{HT}_{3 \mathrm{~A}} \mathrm{R}$ neuron recorded in whole-cell configuration in current clamp . The inset shows intrinsic firing pattern of recorded cell to step current injections. D2, Functional expression of nicotinic ACh receptors in EGFP-positive neurons of 5 HT3aR-BAC ${ }^{E G F P}$ mouse. Nicotine puffing (100 $\mu \mathrm{m}$ for $30 \mathrm{~ms}$ ) depolarizes the $5-\mathrm{HT}_{3 \mathrm{~A}}$ R neuron (D2), but muscarine application (D3) to the same neuron did not change membrane potential, indicating $5-\mathrm{HT}_{3 \mathrm{~A}} \mathrm{R}$ interneurons express nicotinic AChRs (30 ms puff indicated by red line below). The insets in $\mathbf{A 1}$ and $\mathbf{D 1}-\mathbf{D 3}$ show schematics of the recording configuration.

application evoked fast depolarization, often leading to robust firing, in all EGFP-positive cells tested, including all layers (L1, $n=9 ; \mathrm{L} 2 / 3, n=25 ; \mathrm{L} 4, n=6 ; \mathrm{L} 5 / 6, n=5)$ and all subtypes (LS1, $n=12$; LS2, $n=6$; IS, $n=10$; bNA1, $n=11$; bNA2, $n=2$; fAD, $n=3$; dNFS3, $n=1)$. Bath application of tropisetron $(10 \mathrm{nM})$, a $5-\mathrm{HT}_{3 \mathrm{~A}} \mathrm{R}$ specific antagonist, completely blocked the response to mCPBG puffing. As a control, mCPBG was applied to PV-and SST-expressing neurons identified using the B13 (Chattopadhyaya et al., 2004; Dumitriu et al., 2007) and GFP-expressing inhibitory neuron (GIN) (Oliva et al., 2000, Fanselow et al., 2008) transgenic mouse lines, respectively. Neither fast-spiking (FS) $(n=3)$ nor SST $(n=$ 3) neurons showed membrane depolarization in response to $\mathrm{mCPBG}$ application directly onto the soma of the recorded neurons (Fig. 6B, C). These results demonstrate that EGFP-expressing neurons in the cortex of $5 H T 3 a R-B A C^{E G F P}$ mice express functional ionotropic serotonin receptors. It is important to note that careful application of the agonist is required because mCPBG desensitizes the $5-\mathrm{HT}_{3 \mathrm{~A}} \mathrm{R}$ quickly and $\sim 15 \mathrm{~min}$ are required for recovery after a previous puffing.

Single-cell reverse transcription-PCR has shown that neurons that express $5-\mathrm{HT}_{3 \mathrm{~A}} \mathrm{Rs}$ in the cortex and hippocampus of the rat also express nicotinic acetylcholine receptors (Férézou et al., 2002). To confirm this, we tested whether EGFPpositive neurons in $\mathrm{L} 2 / 3$ of the $5 \mathrm{Htr} 3 \mathrm{a}$ $B A C^{E G F P}$ mouse respond to cholinergic and nicotinic agonists. Brief application of the cholinergic agonist carbachol (1 mM; $30 \mathrm{~ms}$ puff) depolarized $5-\mathrm{HT}_{3 \mathrm{~A}} \mathrm{R}$-expressing neurons and evoked bursts of spikes (Fig. 6D1). We further tested which cholinergic receptors are responsible for the depolarization of $5-\mathrm{HT}_{3 \mathrm{~A}} \mathrm{R}$-expressing neurons. Brief application of nicotine (100 $\mu \mathrm{M} ; 30 \mathrm{~ms}$ puff) depolarized 5- $\mathrm{HT}_{3 \mathrm{~A}} \mathrm{R}$-expressing neurons (Fig. 6D2), whereas muscarine (100 $\mu \mathrm{M} ; 30$ ms puff) did not affect the membrane potential of the same neuron (Fig. 6D3). All of the $5-\mathrm{HT}_{3 \mathrm{~A}} \mathrm{R}$-expressing cells tested, including cells in all layers $(\mathrm{L} 1, n=8 ; \mathrm{L} 2 / 3, n=22$; L4, $n=5$; L5/6, $n=6$ ) and of all subtypes (LS1, $n=10$; LS2, $n=3$; IS, $n=9$; bNA1, $n=9$; bNA2, $n=2$; fAD, $n=6$; dNFS3, $n=$

2) responded to nicotine application. Together, these data suggest that both serotonin and acetylcholine can evoke fast synaptic activation of $5-\mathrm{HT}_{3 \mathrm{~A}} \mathrm{R}$-expressing neurons independently of layer and subtype.

\section{Direct thalamocortical synaptic input to}

5-HT ${ }_{3 \mathrm{~A}} \mathrm{R}$-expressing neurons

TC afferents directly contact both excitatory and inhibitory neurons in L4 and deep L3 in the cortex (Agmon and Connors, 1991; Swadlow and Gusev, 2000; Bruno and Simons, 2002; Wehr and 
Zador, 2003; Gabernet et al., 2005; Wilent and Contreras, 2005; Cruikshank et al., 2007, 2010; Hull et al., 2009). Activation of both excitatory and inhibitory neurons establishes a simple disynaptic circuit that provides powerful, local feedforward inhibition because of stronger and faster TC excitation to FS interneurons than to excitatory neurons, which are mainly spiny stellate and star pyramidal neurons (Bruno and Simons, 2002; Swadlow, 2002; Gabernet et al., 2005; Cruikshank et al., 2007, 2010; Hull et al., 2009). Agmon et al. (1991) have suggested that non-FS neurons are also recruited, but the nature of these cells has not been identified. Several lines of evidence suggest that the SSTexpressing population is not recruited by TC stimulation (Beierlein et al., 2003; Cruikshank et al., 2010). We therefore examined whether TC afferents also directly recruit $5-\mathrm{HT}_{3 \mathrm{~A}} \mathrm{R}$ interneurons (Fig. 7). We recorded from $5-\mathrm{HT}_{3 \mathrm{~A}} \mathrm{R}$-expressing neurons in deep L3 and L4 while delivering a brief extracellular stimulus to thalamic afferents with an electrode placed in fibers from VB nucleus of the thalamus in a TC slice preparation (Agmon and Connors, 1991). Evoked EPSCs in 5- $\mathrm{HT}_{3 \mathrm{~A}} \mathrm{R}$ expressing neurons were recorded under voltage-clamp recordings in which the postsynaptic soma was held at $-70 \mathrm{mV}$, while applying electrical stimulation to TC fibers at $20 \mathrm{~Hz}$. For comparison, we also recorded FS from neurons as identified by EGFP expression in the $\mathrm{B} 13$ mouse. To elicit reliable responses, we adjusted the stimulation intensity to twofold higher than minimal stimulation intensity. An average latency of the evoked EP$\mathrm{SCs}$ in $5-\mathrm{HT}_{3 \mathrm{~A}} \mathrm{R}$-expressing neurons measured from the beginning of the stimulation artifact was $3.06 \pm 0.35 \mathrm{~ms}$. This is consistent with previous studies of monosynaptic thalamocortical EPSCs onto excitatory and FS neurons (Porter et al., 2001; Beierlein et al., 2003; Kruglikov and Rudy, 2008). EPSC latency of FS neurons $(2.90 \pm 0.18 \mathrm{~ms})$ did not significantly differ from that on $5-\mathrm{HT}_{3 \mathrm{~A}} \mathrm{R}$-expressing neurons $(p=0.45)$. TC stimulation evoked significantly smaller EPSCs in $5-\mathrm{HT}_{3 \mathrm{~A}} \mathrm{R}$-expressing neurons than in FS (Fig. 7 B, F) $(38.06 \pm 14.13$ vs $240.02 \pm 85.59$ pA; $p=0.0005)$. The synaptic response in a majority of TC-recipient $5-\mathrm{HT}_{3 \mathrm{~A}} \mathrm{R}$-expressing neurons exhibited marked depression of the EPSCs evoked during a train of $20 \mathrm{~Hz}$ TC stimulation (Fig. 7G) (11 of 15 neurons, EPSC2/EPSC1, $0.53 \pm 0.14$ ). A subset of $5-\mathrm{HT}_{3 \mathrm{~A}} \mathrm{R}$-expressing neurons, however, showed either no change or facilitation to repetitive thalamic stimulation (Fig. 7G) ( 4 of 15 neurons, EPSC2/EPSC1, $1.24 \pm 0.08$ ). In contrast, all recorded FS neurons showed strong depression of thalamocortical EPSCs (EPSC2/EPSC1, $0.52 \pm 0.13$ ).

In a subset of recorded $\mathrm{TC}$-recipient $5-\mathrm{HT}_{3 \mathrm{~A}} \mathrm{R}$-expressing neurons, we also measured the depolarization of the membrane potential evoked by thalamic stimulation under current-clamp recording configuration. On average, similarly to the EPSCs, smaller EPSPs were elicited on 5 - $\mathrm{HT}_{3 \mathrm{~A}} \mathrm{R}$-expressing neurons compared with those on FS (Fig. $7 H)(2.88 \pm 0.8$ vs $4.93 \pm 0.75$ $\mathrm{mV} ; p=0.07)$; however, the difference is only less than twofold compared with the sixfold difference in EPSCs, indicating that
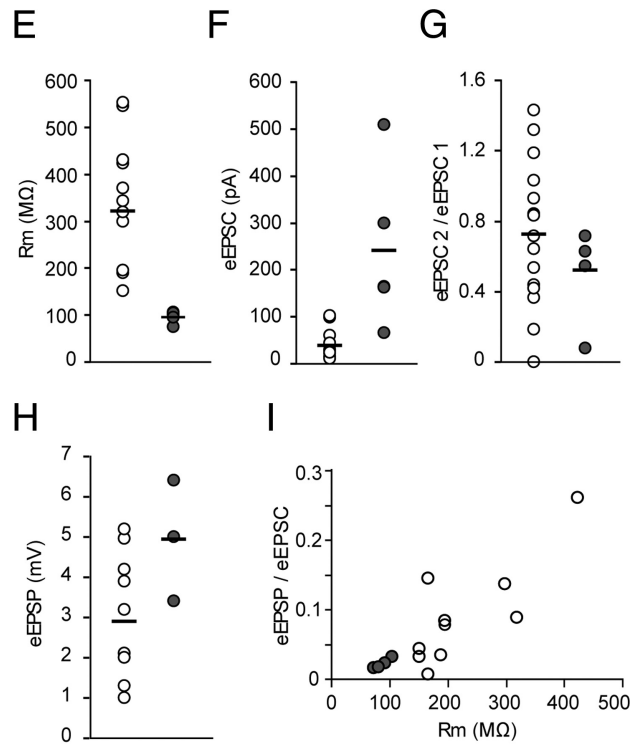

E

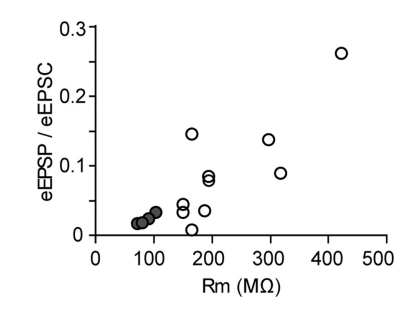

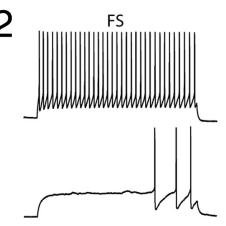

B2

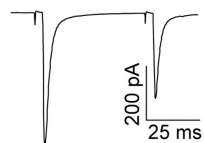

$\mathrm{C} 2$

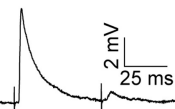

$\mathrm{D} 2$

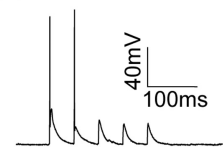

Figure 7. Monosynaptic thalamocortical input to $5-\mathrm{HT}_{3 \mathrm{~A}} \mathrm{R}$-expressing neurons. $\boldsymbol{A}$, Voltage responses of $5-\mathrm{HT}_{3 \mathrm{~A}} \mathrm{R}(\boldsymbol{A} \boldsymbol{1})$ and $\mathrm{FS}$ (A2) neurons to $500 \mathrm{~ms}$ step current injection. $\boldsymbol{B}$, Weak monosynaptic $\mathrm{TC}$ input to $5-\mathrm{HT}_{3 \mathrm{~A}} \mathrm{R}$-expressing neurons. Stimulation of $\mathrm{TC}$

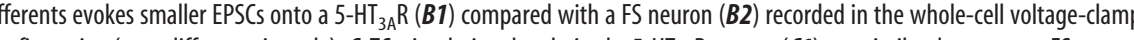
(C). Under current-clamp configuration $(V=-65 \mathrm{mV})$, voltage responses to TC stimulation were recorded from the same . open and filled symbols indicate $5-\mathrm{HT}_{3 \mathrm{~A}} \mathrm{R}$ and $\mathrm{FS}$ neurons, respectively. The bars indicate mean values. $I$, Relationship between input resistance $\left(R_{\mathrm{m}}\right)$ and evoked membrane depolarization (eEPSP) normalized to EPSC in response to TC stimulation.

$5-\mathrm{HT}_{3 \mathrm{~A}} \mathrm{R}$ cells are more responsive to small synaptic currents. Interestingly, in a subset of $5-\mathrm{HT}_{3 \mathrm{~A}} \mathrm{R}$-expressing neurons, $\mathrm{TC}$ stimulation evoked EPSPs comparable with those of FS neurons. As an example, TC stimulation evoked almost nine times smaller synaptic current in an LS1 type $5-\mathrm{HT}_{3 \mathrm{~A}} \mathrm{R}$ neuron (Fig. 7A1) than a FS neuron (Fig. 7B1,B2) (58 and 508 pA, respectively). Despite far less TC synaptic current to the $5-\mathrm{HT}_{3 \mathrm{~A}} \mathrm{R}$ neuron, TC stimulation depolarized the LS1 neuron similar to the FS neuron (Fig. $7 C 1, C 2)(5.4$ and $6.5 \mathrm{mV}$, respectively). The input resistance of the LS1 neuron was three times higher than that of the FS neuron (302 and $98 \mathrm{M} \Omega$, respectively). It is likely that the much higher input resistance of $5-\mathrm{HT}_{3 \mathrm{~A}} \mathrm{R}$ neurons is, in part, responsible for strong depolarization in response to thalamic stimulation. As shown in the example in Figure 7D, thalamic stimulation depolarized this $5-\mathrm{HT}_{3 \mathrm{~A}} \mathrm{R}$ neuron close to threshold and occasionally elicited spikes. Figure $7 I$ shows the correlation between input resistance and EPSPs $\left(R^{2}=0.64\right)$. For each neuron, evoked EPSP was normalized with the evoked EPSC to reveal the relationship between input resistance and changes in membrane potential without the effect of different sizes of synaptic inputs. These results demonstrate that $5-\mathrm{HT}_{3 \mathrm{~A}} \mathrm{R}$-expressing neurons receive weak but direct monosynaptic input from thalamus. Despite weak thalamocortical inputs to $5-\mathrm{HT}_{3 \mathrm{~A}} \mathrm{R}$-expressing neurons, thalamic input can depolarize a subset of $5-\mathrm{HT}_{3 \mathrm{~A}} \mathrm{R}$-expressing neurons to a similar degree as FS neurons, presumably because of their high input resistance.

\section{Discussion}

There is increasing evidence that the high diversity of GABAergic interneurons underpins the functional complexity needed for neural computation (McBain and Fisahn, 2001; Klausberger and 
Somogyi, 2008). Despite the promise that understanding this diversity provides, it is at present challenging to assign particular cortical functions to specific interneuron subtypes. Using a $5 H T 3 a R-B A C^{E G F P}$ transgenic mouse line combined with genetic fate mapping and analysis of neurochemical marker expression, we demonstrate that $5-\mathrm{HT}_{3 \mathrm{~A}} \mathrm{R}$-expressing neurons include the entire spectrum of CGE-derived interneurons and their associated diversity. In fact, $5-\mathrm{HT}_{3 \mathrm{~A}} \mathrm{R}$ expression labels all interneurons except the MGE-derived PV and SST populations and the progenitors that give rise to them. We discovered that, in addition to the functional expression of $5-\mathrm{HT}_{3 \mathrm{~A}} \mathrm{Rs}$, these cells could also be recruited robustly by cholinergic stimulation. Interestingly, we also found that some $5-\mathrm{HT}_{3 \mathrm{~A}} \mathrm{R}$ neurons in TCrecipient areas receive weak but potentially significant direct monosynaptic inputs from thalamus, and that a subset of $5-\mathrm{HT}_{3 \mathrm{~A}} \mathrm{R}$ neurons was depolarized as strongly as FS cells by this weak input. The ability of this population to respond to serotonergic and cholinergic transmission provides a convergent means for quickly altering cortical activity through an enhancement of GABAergic synaptic transmission depending on different behavioral states.

\section{5-HT ${ }_{3 \mathrm{~A}} \mathrm{R}$-expressing neurons and cortical interneuron diversity}

Interneurons in cortex comprise $15-20 \%$ of all cortical neurons in rodents (Gabbott and Somogyi, 1986; DeFelipe and Fariñas, 1992; Beaulieu, 1993; Tamamaki et al., 2003). Of this population, as much as $60 \%$ have been traditionally thought to be FS neurons (Xu et al., 2004; Butt et al., 2005; Gonchar et al., 2007). Recently, using the neuronal marker reelin (together with SST) and VIP as CGE markers, we discovered that the contribution of cells derived from the CGE has been underestimated, and in fact this population comprises as much as $30 \%$ of all cortical interneurons (Miyoshi et al., 2010). Furthermore, in this same study, we also found that the peak of CGE interneuron production was considerably later than that observed in the MGE (E16.5 and E14.5 respectively). The present finding extends our understanding of this population by demonstrating that most if not all CGEderived interneurons express $5-\mathrm{HT}_{3 \mathrm{~A}} \mathrm{R}$, whereas MGE-derived PV and SST interneurons do not. Here, we demonstrate that the size, breadth, and diversity of this population are considerably larger than had been recognized.

This study, along with that by Miyoshi et al. (2010), suggests that there is a population of cortical interneurons derived from outside the MGE that does not label with any known marker. This percentage seems slightly higher in this study, which could be attributable to the fact that $5 H T 3 a R-B A C^{E G F P}$ also labels cells outside the ganglionic eminences embryonically, most notably the POA. A majority of cortical interneurons derived from the POA, as labeled by $N k \times 5-1^{C r e}$ genetic fate mapping, have been show to lack known markers (Gelman et al., 2009). Consistent with this hypothesis, we observed EGFP-labeled interneurons with similar morphological and electrophysiological characteristics to those described by Gelman et al. (2009). Our present observation that $5-\mathrm{HT}_{3 \mathrm{~A}} \mathrm{R}$-expressing neurons constitute $\sim 30 \%$ of cortical interneurons adds to the growing evidence that the size and diversity of the non-FS population of interneurons have been underestimated. In fact, we find that, in supragranular cortical layers, $5-\mathrm{HT}_{3 \mathrm{~A}} \mathrm{R}$ interneurons are the predominant interneuron population.

\section{Heterogeneity within the $5-\mathrm{HT}_{3 \mathrm{~A}} \mathrm{R}$-expressing} interneuron population

A previous study using unsupervised cluster analysis divided the $5-\mathrm{HT}_{3 \mathrm{~A}} \mathrm{R}$ interneurons into two cell types: "NPY-" and "VIPcluster," describing them as multipolar and bipolar, respectively (Vucurovic et al., 2010). Our systematic analysis of the $5-\mathrm{HT}_{3 \mathrm{~A}} \mathrm{R}-$ expressing population suggests that the diversity of these neurons is much larger. We find that $>35 \%$ of $5-\mathrm{HT}_{3 \mathrm{~A}} \mathrm{R}$-expressing neurons do not express NPY or VIP. Furthermore, we show that $5-\mathrm{HT}_{3 \mathrm{~A}} \mathrm{R}$ neurons contain the entire CGE-derived population, which was previously shown to be composed of at least nine different morphological and electrophysiological subtypes (Miyoshi et al., 2010). This suggests that some caution and nuance is warranted when doing detailed analysis of the functional aspects of this population. Indeed, it is reasonable to assume that some of the heterogeneity that we see in the physiology is a reflection of functional diversity. For example, VIPor NPY-expressing neurons can modulate the contraction and dilatation of nearby microvessels by releasing VIP or NPY (Cauli et al., 2004; Kocharyan et al., 2008). Thus, the activity of these neurons can potentially regulate local blood flow. Neurogliaform neurons, which presumably correspond to the LS1 subtype of $5-\mathrm{HT}_{3 \mathrm{~A}} \mathrm{R}$ neurons, release GABA by volume transmission, thus providing long-lasting inhibition to local circuits (Tamás et al., 2003; Oláh et al., 2009). Despite this, most $5-\mathrm{HT}_{3 \mathrm{~A}} \mathrm{R}$ neurons share a developmental origin, as well as responsiveness to both serotonergic and cholinergic ascending pathways.

\section{Functional implications of the presence of ionotropic serotonergic and acetylcholine receptors within a subpopulation of cortical interneurons}

Despite the heterogeneity in the $5-\mathrm{HT}_{3 \mathrm{~A}} \mathrm{R}$-expressing population, they all share fast modulation by ionotropic serotonergic and cholinergic receptors. It is possible that their contribution to cortical neural function is dependent on brain state and behavioral context. Perhaps $5-\mathrm{HT}_{3 \mathrm{~A}} \mathrm{R}$-expressing neurons are strongly engaged in sensory processes in specific contexts, but otherwise may provide only a weak source of inhibition within the upper layers of cortex, where they reside most prominently.

The highly biased distribution of $5-\mathrm{HT}_{3 \mathrm{~A}} \mathrm{R}$ interneurons in superficial layers, especially L1, suggests that they can inhibit not only nearby neurons within superficial layers but also pyramidal neurons in infragranular layers, which project their apical dendrite to superficial layers (Markram et al., 2004). Supporting this notion, pharmacological blockade of $5-\mathrm{HT}_{3 \mathrm{~A}}$ Rs has been found to change inhibitory and excitatory tone in L5 pyramidal neurons in response to local electrical stimulation in L2/3 (Moreau et al., 2010).

\section{5-HT ${ }_{3 \mathrm{~A}} \mathrm{R}$-expressing neurons as recipients of thalamocortical input}

In vivo and in vitro studies of thalamocortical circuits report stronger, faster, and more converging projections from TC to FS neurons than to excitatory neurons (Agmon and Connors, 1991; Bruno and Simons, 2002; Swadlow, 2002; Wehr and Zador, 2003; Gabernet et al., 2005; Cruikshank et al., 2007; Hull et al., 2009). Such a bias creates strong disynaptic feedforward inhibition, resulting in spatiotemporally sharpening of incoming subcortical sensory inputs (Miller et al., 2001; Pinto et al., 2003). Lowthreshold spiking (LTS) interneurons, which originate from 
MGE and express SST, receive sparse and weak input from thalamus compared with FS (Beierlein et al., 2003). LTS neurons are thought to be involved in feedback inhibition (Beierlein et al., 2003; Kapfer et al., 2007; Silberberg and Markram, 2007; Fanselow et al., 2008). Others have reported that "regular-spiking nonpyramidal interneurons" (RSNP), which are characterized by spike frequency adaptation, receive direct synaptic contacts from TC neurons (Porter et al., 2001). TC stimulation evoked spikes in both a subset of RSNP and FS neurons to a similar degree. The characterization of the RSNP cells receiving TC input in the study by Porter et al. (2001) was insufficient to definitely determine the subtypes, but it is highly likely that at least some of them correspond to $5-\mathrm{HT}_{3 \mathrm{~A}} \mathrm{R}$ cells. Under our experimental conditions, $\sim 65 \%$ of $5-\mathrm{HT}_{3 \mathrm{~A}} \mathrm{R}$-expressing neurons in deep layer 3 and layer 4 received weak but monosynaptic inputs from TC stimulation. Despite the small TC synaptic current recorded in $5-\mathrm{HT}_{3 \mathrm{~A}} \mathrm{R}$-expressing neurons, TC stimulation strongly depolarized a subset of these TC recipients similar to FS neurons. This can be explained, in part, as a result of their high input resistance.

Our finding of strong depolarization of a subset of $5-\mathrm{HT}_{3 \mathrm{~A}} \mathrm{R}$ neurons in response to TC stimulation raises the possibility that these $5-\mathrm{HT}_{3 \mathrm{~A}} \mathrm{R}$ neurons can contribute to feedforward inhibition in TC circuits. The dynamics of feedforward inhibition by $5-\mathrm{HT}_{3 \mathrm{~A}} \mathrm{R}$ neurons, however, may differ compared with that by FS neurons. Some of the TC-recipient $5-\mathrm{HT}_{3 \mathrm{~A}} \mathrm{R}$ neurons could predominantly inhibit other interneurons, including FS neurons, and thus indirectly relieve excitatory neurons from feedforward inhibition. Anatomical evidence supports that a majority of FS neurons in S1 cortex receive synaptic contacts from VIP neurons (Dávid et al., 2007).

Serotonin and ACh may sensitize $5-\mathrm{HT}_{3 \mathrm{~A}} \mathrm{R}$ neurons and increase their responsiveness to TC input, thus making feedforward inhibition of TC inputs or the relief of excitatory neurons from feedforward inhibition dependent on behavioral state. Understanding the mechanisms by which serotonergic and/or cholinergic afferents on these TC-recipient $5-\mathrm{HT}_{3 \mathrm{~A}} \mathrm{R}$ neurons modulate sensory input, will no doubt add considerably to our understanding of cortical circuitry.

In future studies, it will be important to investigate the synaptic connectivity among FS, pyramidal, and $5-\mathrm{HT}_{3 \mathrm{~A}} \mathrm{R}$ neurons, to understand dynamics of cortical circuits and how these synaptic properties are modulated by serotonin and acetylcholine. Extending this line of studies to in vivo preparations will be important to understand how $5-\mathrm{HT}_{3 \mathrm{~A}} \mathrm{R}$ neurons are engaged in network dynamics in the context of sensory processing in cortex during different brain states.

\section{References}

Agmon A, Connors BW (1991) Thalamocortical responses of mouse somatosensory (barrel) cortex in vitro. Neuroscience 41:365-379.

Anderson SA, Qiu M, Bulfone A, Eisenstat DD, Meneses J, Pedersen R, Rubenstein JL (1997a) Mutations of the homeobox genes Dlx-1 and Dlx-2 disrupt the striatal subventricular zone and differentiation of late born striatal neurons. Neuron 19:27-37.

Anderson SA, Eisenstat DD, Shi L, Rubenstein JL (1997b) Interneuron migration from basal forebrain to neocortex: dependence on Dlx genes. Science 278:474-476.

Ascoli GA, Alonso-Nanclares L, Anderson SA, Barrionuevo G, BenavidesPiccione R, Burkhalter A, Buzsáki G, Cauli B, Defelipe J, Fairén A, Feldmeyer D, Fishell G, Fregnac Y, Freund TF, Gardner D, Gardner EP, Goldberg JH, Helmstaedter M, Hestrin S, Karube F, et al. (2008) Petilla terminology: nomenclature of features of GABAergic interneurons of the cerebral cortex. Nat Rev Neurosci 9:557-568.
Barnes NM, Sharp T (1999) A review of central 5-HT receptors and their function. Neuropharmacology 38:1083-1152.

Battiste J, Helms AW, Kim EJ, Savage TK, Lagace DC, Mandyam CD, Eisch AJ, Miyoshi G, Johnson JE (2007) Ascll defines sequentially generated lineage-restricted neuronal and oligodendrocyte precursor cells in the spinal cord. Development 134:285-293.

Beaulieu C (1993) Numerical data on neocortical neurons in adult rat, with special reference to the GABA population. Brain Res 609:284-292.

Beaulieu C, Somogyi P (1991) Enrichment of cholinergic synaptic terminals on GABAergic neurons and coexistence of immunoreactive GABA and choline acetyltransferase in the same synaptic terminals in the striate cortex of the cat. J Comp Neurol 304:666-680.

Beierlein M, Gibson JR, Connors BW (2003) Two dynamically distinct inhibitory networks in layer 4 of the neocortex. J Neurophysiol 90: 2987-3000.

Bhat RV, Axt KJ, Fosnaugh JS, Smith KJ, Johnson KA, Hill DE, Kinzler KW, Baraban JM (1996) Expression of the APC tumor suppressor protein in oligodendroglia. Glia 17:169-174.

Britanova O, de Juan Romero C, Cheung A, Kwan KY, Schwark M, Gyorgy A, Vogel T, Akopov S, Mitkovski M, Agoston D, Sestan N, Molnár Z, Tarabykin V (2008) Satb2 is a postmitotic determinant for upper-layer neuron specification in the neocortex. Neuron 57:378-392.

Bruno RM, Simons DJ (2002) Feedforward mechanisms of excitatory and inhibitory cortical receptive fields. J Neurosci 22:10966-10975.

Butt SJ, Fuccillo M, Nery S, Noctor S, Kriegstein A, Corbin JG, Fishell G (2005) The temporal and spatial origins of cortical interneurons predict their physiological subtype. Neuron 48:591-604.

Buzsáki G, Geisler C, Henze DA, Wang XJ (2004) Interneuron diversity series: circuit complexity and axon wiring economy of cortical interneurons. Trends Neurosci 27:186-193.

Caputi A, Rozov A, Blatow M, Monyer H (2009) Two calretinin-positive GABAergic cell types in layer 2/3 of the mouse neocortex provide different forms of inhibition. Cereb Cortex 19:1345-1359.

Cauli B, Audinat E, Lambolez B, Angulo MC, Ropert N, Tsuzuki K, Hestrin S, Rossier J (1997) Molecular and physiological diversity of cortical nonpyramidal cells. J Neurosci 17:3894-3906.

Cauli B, Porter JT, Tsuzuki K, Lambolez B, Rossier J, Quenet B, Audinat E (2000) Classification of fusiform neocortical interneurons based on unsupervised clustering. Proc Natl Acad Sci U S A 97:6144-6149.

Cauli B, Tong XK, Rancillac A, Serluca N, Lambolez B, Rossier J, Hamel E (2004) Cortical GABA interneurons in neurovascular coupling: relays for subcortical vasoactive pathways. J Neurosci 24:8940-8949.

Chameau P, van Hooft JA (2006) Serotonin 5- $\mathrm{HT}_{3}$ receptors in the central nervous system. Cell Tissue Res 326:573-581.

Chameau P, Inta D, Vitalis T, Monyer H, Wadman WJ, van Hooft JA (2009) The N-terminal region of reelin regulates postnatal dendritic maturation of cortical pyramidal neurons. Proc Natl Acad Sci U S A 106:7227-7232.

Chattopadhyaya B, Di Cristo G, Higashiyama H, Knott GW, Kuhlman SJ, Welker E, Huang ZJ (2004) Experience and activity-dependent maturation of perisomatic GABAergic innervation in primary visual cortex during a postnatal critical period. J Neurosci 24:9598-9611.

Chu Z, Galarreta M, Hestrin S (2003) Synaptic interactions of late-spiking neocortical neurons in layer 1. J Neurosci 23:96-102.

Cobos I, Long JE, Thwin MT, Rubenstein JL (2006) Cellular patterns of transcription factor expression in developing cortical interneurons. Cereb Cortex [Suppl 1]:i82-i88.

Cruikshank SJ, Lewis TJ, Connors BW (2007) Synaptic basis for intense thalamocortical activation of feedforward inhibitory cells in neocortex. Nat Neurosci 10:462-468.

Cruikshank SJ, Urabe H, Nurmikko AV, Connors BW (2010) Pathwayspecific feedforward circuits between thalamus and neocortex revealed by selective optical stimulation of axons. Neuron 65:230-245.

Dávid C, Schleicher A, Zuschratter W, Staiger JF (2007) The innervation of parvalbumin-containing interneurons by VIP-immunopositive interneurons in the primary somatosensory cortex of the adult rat. Eur J Neurosci 25:2329-2340.

DeFelipe J, Fariñas I (1992) The pyramidal neuron of the cerebral cortex: morphological and chemical characteristics of the synaptic inputs. Prog Neurobiol 39:563-607.

Dumitriu D, Cossart R, Huang J, Yuste R (2007) Correlation between ax- 
onal morphologies and synaptic input kinetics of interneurons from mouse visual cortex. Cereb Cortex 17:81-91.

Fanselow EE, Richardson KA, Connors BW (2008) Selective, statedependent activation of somatostatin-expressing inhibitory interneurons in mouse neocortex. J Neurophysiol 100:2640-2652.

Férézou I, Cauli B, Hill EL, Rossier J, Hamel E, Lambolez B (2002) 5-HT receptors mediate serotonergic fast synaptic excitation of neocortical vasoactive intestinal peptide/cholecystokinin interneurons. J Neurosci 22:7389-7397.

Freund TF (2003) Interneuron diversity series: rhythm and mood in perisomatic inhibition. Trends Neurosci 26:489-495.

Freund TF, Buzsáki G (1996) Interneurons of the hippocampus. Hippocampus 6:347-470.

Gabbott PL, Somogyi P (1986) Quantitative distribution of GABAimmunoreactive neurons in the visual cortex (area 17) of the cat. Exp Brain Res 61:323-331.

Gabernet L, Jadhav SP, Feldman DE, Carandini M, Scanziani M (2005) Somatosensory integration controlled by dynamic thalamocortical feedforward inhibition. Neuron 48:315-327.

Galarreta M, Erdélyi F, Szabó G, Hestrin S (2004) Electrical coupling among irregular-spiking GABAergic interneurons expressing cannabinoid receptors. J Neurosci 24:9770-9778.

Gelman DM, Martini FJ, Nóbrega-Pereira S, Pierani A, Kessaris N, Marín O (2009) The embryonic preoptic area is a novel source of cortical GABAergic interneurons. J Neurosci 29:9380-9389.

Gonchar Y, Wang Q, Burkhalter A (2007) Multiple distinct subtypes of GABAergic neurons in mouse visual cortex identified by triple immunostaining. Front Neuroanat 1:3.

Hull C, Isaacson JS, Scanziani M (2009) Postsynaptic mechanisms govern the differential excitation of cortical neurons by thalamic inputs. J Neurosci 29:9127-9136.

Inta D, Alfonso J, von Engelhardt J, Kreuzberg MM, Meyer AH, van Hooft JA, Monyer H (2008) Neurogenesis and widespread forebrain migration of distinct GABAergic neurons from the postnatal subventricular zone. Proc Natl Acad Sci U S A 105:20994-20999.

Kapfer C, Glickfeld LL, Atallah BV, Scanziani M (2007) Supralinear increase of recurrent inhibition during sparse activity in the somatosensory cortex. Nat Neurosci 10:743-753.

Karagiannis A, Gallopin T, Dávid C, Battaglia D, Geoffroy H, Rossier J, Hillman EM, Staiger JF, Cauli B (2009) Classification of NPYexpressing neocortical interneurons. J Neurosci 29:3642-3659.

Kawaguchi Y (1995) Physiological subgroups of nonpyramidal cells with specific morphological characteristics in layer II/III of rat frontal cortex. J Neurosci 15:2638-2655.

Kawaguchi Y, Kubota Y (1996) Physiological and morphological identification of somatostatin- or vasoactive intestinal polypeptide-containing cells among GABAergic cell subtypes in rat frontal cortex. J Neurosci 16:2701-2715.

Kawaguchi Y, Kubota Y (1997) GABAergic cell subtypes and their synaptic connections in rat frontal cortex. Cereb Cortex 7:476-486.

Klausberger T, Somogyi P (2008) Neuronal diversity and temporal dynamics: the unity of hippocampal circuit operations. Science 321:53-57.

Kocharyan A, Fernandes P, Tong XK, Vaucher E, Hamel E (2008) Specific subtypes of cortical GABA interneurons contribute to the neurovascular coupling response to basal forebrain stimulation. J Cereb Blood Flow Metab 28:221-231.

Kruglikov I, Rudy B (2008) Perisomatic GABA release and thalamocortical integration onto neocortical excitatory cells are regulated by neuromodulators. Neuron 58:911-924.

Lewis DA, Hashimoto T (2007) Deciphering the disease process of schizophrenia: the contribution of cortical GABA neurons. Int Rev Neurobiol 78:109-131.

Lu QR, Yuk D, Alberta JA, Zhu Z, Pawlitzky I, Chan J, McMahon AP, Stiles CD, Rowitch DH (2000) Sonic hedgehog-regulated oligodendrocyte lineage genes encoding $\mathrm{bHLH}$ proteins in the mammalian central nervous system. Neuron 25:317-329.

Luche H, Weber O, Nageswara Rao T, Blum C, Fehling HJ (2007) Faithful activation of an extra-bright red fluorescent protein in "knock-in" Crereporter mice ideally suited for lineage tracing studies. Eur J Immunol 37:43-53.

Markram H, Toledo-Rodriguez M, Wang Y, Gupta A, Silberberg G, Wu C
(2004) Interneurons of the neocortical inhibitory system. Nat Rev Neurosci 5:793-807.

McBain CJ, Fisahn A (2001) Interneurons unbound. Nat Rev Neurosci 2:11-23.

Miller KD, Pinto DJ, Simons DJ (2001) Processing in layer 4 of the neocortical circuit: new insights from visual and somatosensory cortex. Curr Opin Neurobiol 11:488-497.

Miyoshi G, Butt SJ, Takebayashi H, Fishell G (2007) Physiologically distinct temporal cohorts of cortical interneurons arise from telencephalic Olig2expressing precursors. J Neurosci 27:7786-7798.

Miyoshi G, Hjerling-Leffler J, Karayannis T, Sousa VH, Butt SJ, Battiste J, Johnson JE, Machold RP, Fishell G (2010) Genetic fate mapping reveals that the caudal ganglionic eminence produces a large and diverse population of superficial cortical interneurons. J Neurosci 30:1582-1594.

Morales M, Bloom FE (1997) The $5-\mathrm{HT}_{3}$ receptor is present in different subpopulations of GABAergic neurons in the rat telencephalon. J Neurosci 17:3157-3167.

Moreau AW, Amar M, Le Roux N, Morel N, Fossier P (2010) Serotoninergic fine-tuning of the excitation-inhibition balance in rat visual cortical networks. Cereb Cortex 20:456-467.

Nery S, Fishell G, Corbin JG (2002) The caudal ganglionic eminence is a source of distinct cortical and subcortical cell populations. Nat Neurosci 5:1279-1287.

Oláh S, Komlósi G, Szabadics J, Varga C, Tóth E, Barzó P, Tamás G (2007) Output of neurogliaform cells to various neuron types in the human and rat cerebral cortex. Front Neural Circuits 1:4.

Oláh S, Füle M, Komlósi G, Varga C, Báldi R, Barzó P, Tamás G (2009) Regulation of cortical microcircuits by unitary GABA-mediated volume transmission. Nature 461:1278-1281.

Oliva AA Jr, Jiang M, Lam T, Smith KL, Swann JW (2000) Novel hippocampal interneuronal subtypes identified using transgenic mice that express green fluorescent protein in GABAergic interneurons. J Neurosci 20:3354-3368.

Pesold C, Liu WS, Guidotti A, Costa E, Caruncho HJ (1999) Cortical bitufted, horizontal, and Martinotti cells preferentially express and secrete reelin into perineuronal nets, nonsynaptically modulating gene expression. Proc Natl Acad Sci U S A 96:3217-3222.

Pinto DJ, Hartings JA, Brumberg JC, Simons DJ (2003) Cortical damping: analysis of thalamocortical response transformations in rodent barrel cortex. Cereb Cortex 13:33-44.

Porter JT, Cauli B, Staiger JF, Lambolez B, Rossier J, Audinat E (1998) Properties of bipolar VIPergic interneurons and their excitation by pyramidal neurons in the rat neocortex. Eur J Neurosci 10:3617-3628.

Porter JT, Johnson CK, Agmon A (2001) Diverse types of interneurons generate thalamus-evoked feedforward inhibition in the mouse barrel cortex. J Neurosci 21:2699-2710.

Rozov A, Jerecic J, Sakmann B, Burnashev N (2001) AMPA receptor channels with long-lasting desensitization in bipolar interneurons contribute to synaptic depression in a novel feedback circuit in layer $2 / 3$ of rat neocortex. J Neurosci 21:8062-8071.

Silberberg G, Markram H (2007) Disynaptic inhibition between neocortical pyramidal cells mediated by Martinotti cells. Neuron 53:735-746.

Smiley JF, Goldman-Rakic PS (1996) Serotonergic axons in monkey prefrontal cerebral cortex synapse predominantly on interneurons as demonstrated by serial section electron microscopy. J Comp Neurol 367:431-443.

Swadlow HA (2002) Thalamocortical control of feed-forward inhibition in awake somatosensory "barrel” cortex. Philos Trans R Soc Lond B Biol Sci 357:1717-1727.

Swadlow HA, Gusev AG (2000) The influence of single VB thalamocortical impulses on barrel columns of rabbit somatosensory cortex. J Neurophysiol 83:2802-2813.

Tamamaki N, Yanagawa Y, Tomioka R, Miyazaki J, Obata K, Kaneko T (2003) Green fluorescent protein expression and colocalization with calretinin, parvalbumin, and somatostatin in the GAD67-GFP knock-in mouse. J Comp Neurol 467:60-79.

Tamás G, Lorincz A, Simon A, Szabadics J (2003) Identified sources and targets of slow inhibition in the neocortex. Science 299:1902-1905.

Varga V, Losonczy A, Zemelman BV, Borhegyi Z, Nyiri G, Domonkos A, Hangya B, Holderith N, Magee JC, Freund TF (2009) Fast synaptic subcortical control of hippocampal circuits. Science 326:449-453. 
Vucurovic K, Gallopin T, Ferezou I, Rancillac A, Chameau P, van Hooft JA, Geoffroy H, Monyer H, Rossier J, Vitalis T (2010) Serotonin 3A receptorsubtype as an early and protracted marker of cortical interneuron subpopulations. Cereb Cortex 20:2333-2347.

Wehr M, Zador AM (2003) Balanced inhibition underlies tuning and sharpens spike timing in auditory cortex. Nature 426:442-446.

Wichterle H, Garcia-Verdugo JM, Herrera DG, Alvarez-Buylla A (1999) Young neurons from medial ganglionic eminence disperse in adult and embryonic brain. Nat Neurosci 2:461-466.

Wichterle H, Turnbull DH, Nery S, Fishell G, Alvarez-Buylla A (2001) In utero fate mapping reveals distinct migratory pathways and fates of neurons born in the mammalian basal forebrain. Development 128:3759-3771.

Wilent WB, Contreras D (2005) Dynamics of excitation and inhibition un- derlying stimulus selectivity in rat somatosensory cortex. Nat Neurosci 8:1364-1370.

Wonders CP, Anderson SA (2006) The origin and specification of cortical interneurons. Nat Rev Neurosci 7:687-696.

Xu Q, Cobos I, De La Cruz E, Rubenstein JL, Anderson SA (2004) Origins of cortical interneuron subtypes. J Neurosci 24:2612-2622.

Xu Q, Tam M, Anderson SA (2008) Fate mapping Nkx2.1-lineage cells in the mouse telencephalon. J Comp Neurol 506:16-29.

Zagha E, Goldberg EM, Stevens TR, Ma G, Heintz N, Rudy B (2005) Probing cortical GABAergic interneuron diversity using BAC transgenic mice. Soc Neurosci Abstr 31:625.1.

Zhou Q, Anderson DJ (2002) The bHLH transcription factors OLIG2 and OLIG1 couple neuronal and glial subtype specification. Cell 109:61-73. 